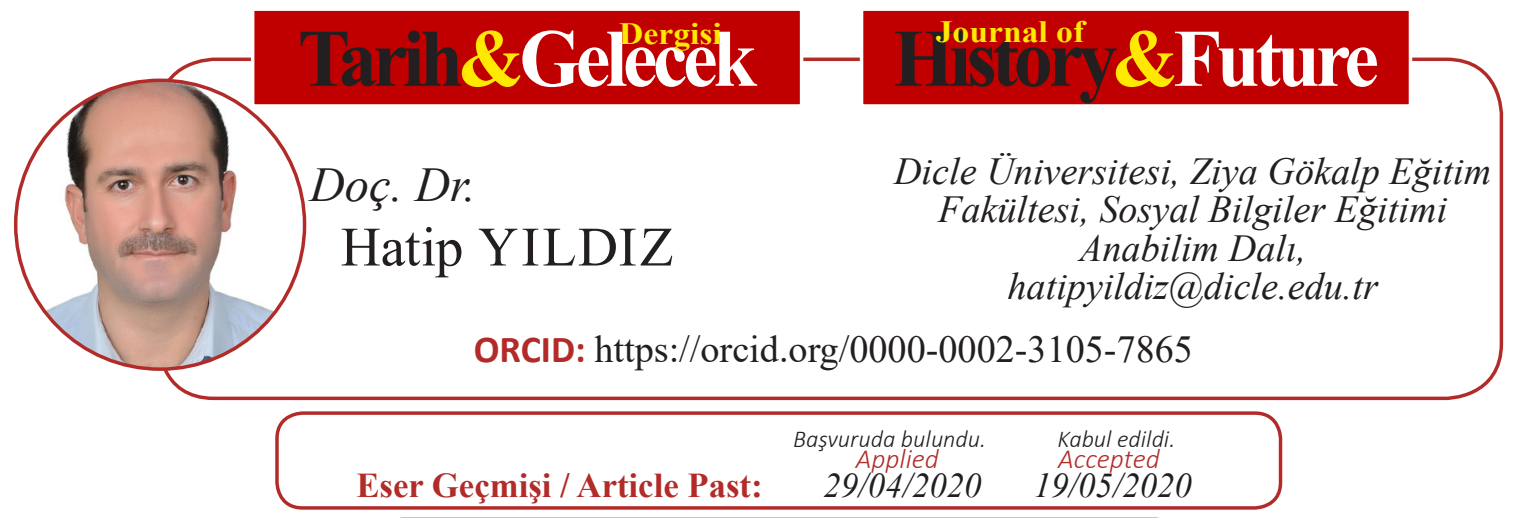

DOI: http://dx.doi.org/10.21551/jhf.729167

Research Paper

Orjinal Makale / Orginal Paper

\title{
Osmanlı Modernleşme Döneminde Urfa Sancağında Açılan Müslüman Rüşdiye Mektepleri
}

\author{
The Muslim Rushdie Schools Opened in Urfa Sanjak During The \\ Ottoman Modernization Period
}

$\ddot{O} z$

Osmanlı Devleti'nde, Tanzimat Fermanı'nın ilanından sonra daha planlı bir şekilde yürütülen modernleşme çalışmaları, İstanbul'un yanı sira, vilayetlerde de peyderpey etkisini göstermiştir. Bu dönemde, merkezde olduğu gibi, taşrada da yenilik yapılan alanlardan biri de eğitimdir. Bu doğrultuda vilayetlerde farklı düzeylerde pek çok modern okul açılmaya başlanmıştır.

Osmanlı'nın diğer birçok vilayet, sancak ve kazalarında olduğu gibi, bugünkü Şanlıurfa ili ve ilçelerinin önemli bir kısmını içine alan Urfa Sancağında da ilk açılan Müslüman modern okullart sivil rüşdiye mektepleri olmuştur. Bunlar; Urfa Rüşdiye Mektebi, Birecik Rüşdiye Mektebi, Rumkale (Halfeti) Rüşdiye Mektebi ve Nizib Rüşdiye Mektebidir.

Bu çalışmada; söz konusu rüşdiye mekteplerinin açıllışları ile öğretmen, ögrenci, ders ve eğitim durumlarl ayrıntılı bir şekilde incelenerek, Urfa'nın Osmanlı dönemindeki modern ortaokul eğitim yapısı ortaya konulmuştur. Ayrıca, sözü edilen rüşdiyelerin, daha sonra bölgede açılan diğer yeni okulları nasıl etkilediği; sıbyan ve ibtidai mezunlarının eğitimlerini sürdürmelerinde ne tür bir katklsının olduğu değerlendirilmiştir.

Çalışmanın hazırlanmasında; Osmanlı Devlet Salnameleri, Haleb Vilayet Salnameleri, Maarif Salnameleri, Başbakanlık Osmanlı Arşivi Maarif Nezareti tasnifi belgeleri ve konuyla ilgili araştırma eserlerden faydalanılmıştır.

Anahtar kelimeler: Osmanlı, Urfa, eğitim, rüşdiye, ortaokul. 


\section{Abstract}

In the Ottoman State, after the announcement of the Tanzimat, the efforts of renewal, which had started in a more planned manner, showed the influence of gradually in the provinces outside Istanbul. In this period, as in the center, one of the innovation areas in the province is education. In this direction, many modern schools have been opened at different levels in the provinces.

As in many other provinces and sanjaks of the Ottoman, in the Urfa region, which contains a significant part of the present Şanliurfa province, the schools that were first opened were the rushdies. These are Urfa Rushdie School, Birecik Rushdie School, Rumkale (Halfeti) Rushdie School and Nizip Rushdie School.

In this study; opening of the rushdie schools, students, teachers, classes and educational status were examined in detail. Thus, the modern education structure of the Urfa Sanjak has been revealed. In addition, has been evaluated how these schools affect other modern schools that later opened in the sanjak.

In the preparation of the work; Ottoman State Yearbooks, Education Yearbooks, Provinces Yearbooks, Documents of the Ministry of Education in the Ottoman Archives of the Prime Ministry and related research works will be used.

Keywords: Ottoman, Urfa, education, rushdie, secondary school.

\section{Giriş}

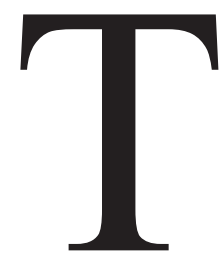

arih boyunca çeşitli uygarlıkların yaşadığı Urfa bölgesi, Yavuz Sultan Selim'in Ridaniye Savaşı dönüşünde (1517) Osmanlı Devleti'nin hâkimiyetine girmiştir.' Bu tarihten itibaren farklı statülerle idare edilen bölge, Osmanlı son dönemlerinde genellikle Halep Vilayetine bağlı bir sancak olarak idari yapısını sürdürmüştür. ${ }^{2}$ Sancak dâhilinde de II. Abdülhamid Dönemi sonuna kadar Birecik, Rumkale, Suruç ve Harran kazaları yer almıştır. ${ }^{3}$

Osmanlı Devleti'nin 17. yüzyılın sonlarından itibaren savaşlarda aldı̆̆ yenilgiler, o zamana kadar verilen askeri eğitimin artık yetersiz kaldığını ortaya koymuştur. Bu durum, 18. yüzyılda Avrupa tarzında yeni askeri okulların açılmasına neden olmuştur. Fakat Osmanlı'nın temel eğitim kurumları olan ve aynı zamanda askeri okullara da talebe yetiştiren sıbyan mektepleri ile sözü edilen askeri okullar arasında eğitim düzeyi bakımından büyük bir uçurum vardır. Bu nedenle, sıbyan mektepleri ile askeri okullar arasında yer alan ve "rüşdiye" adı verilen yeni bir okul türünün açılmasına ihtiyaç duyulmuştur. ${ }^{4}$

Osmanlı'da ilk olarak açılan ve kendine özgü yönleri bulunan rüşdiye mektepleri; 1839

1 Mehmet Emin Üner, Osmanlı Klasik Dönem Sonlarında Bir Güneydoğu Anadolu Şehri: Urfa (17001800), Yayımlanmamış Doktora Tezi, İstanbul Üniversitesi Sosyal Bilimler Enstitüsü, İstanbul 2003, s. 10.

2 Abdullah Ekinci, Kazım Paydaş, "Kuruluşundan Osmanlı Hâkimiyetine: Urfa Siyasi Tarihi”, Osmanlı Urfas1, Cilt: 1, Editör: Abdullah Ekinci, Edessa Yayınları, İstanbul 2018, s. 25.

3 Haleb Vilayet Salnamesi, H. 1326, s. 404.

4 Yahya Akyüz, Türk Eğitim Tarihi (Başlangıçtan 1999’a), Alfa Yayınları, İstanbul 1999, s. 129. 
y1lında açılan Mekteb-i Maarif-i Adliyye ile Mekteb-i Ulûm-1 Edebiyye-i Adliyye'dir. Bu iki okul, Babıâli'ye memur yetiştirmeye devam ettiği halde, yeni ihtiyaçlara ve Tanzimat Dönemi'nin reformlarına 1 şık tutmaktan uzaktır. Bu nedenle, orta dereceli okullar olan rüşdiyelerin yeniden yapılandırılmasına ve yeni okulların açılmasına teşebbüs edilmiştir. ${ }^{5} \mathrm{Bu}$ çerçevede, Sultan Abdülmecid'in emri doğrultusunda 1845'te kurulan Muvakkat (Geçici) Maarif Meclisinde ${ }^{6}$, Bilâd-1 selâse (Üsküdar, Galata ve Eyüp) ile Boğaziçi'nde ilk etapta 30 adet ve taşrada dahi gerektiği kadar rüşdiye mektebi açılması uygun görülmüştür. Ancak numune olmak üzere ilk olarak Dersaadet'te 4 ve Üsküdar'da 1 sıbyan mektebi rüşdiyeye dönüştürülmüştür. ${ }^{7}$ Böylece, 1847 yılında başlangıç olarak İstanbul'da Davud Paşa, Bayezid, Üsküdar, Tophane ve Babıâli civarında Ağa Camii'nde olmak üzere 5 adet rüşdiye mektebi açılmıştır. ${ }^{8}$

İstanbul'da rüşdiyeler epeyce gelişip yaygınlaşınca vilayetlerde de açılması planlanmıştır. Vilayetlerde rüşdiye mekteplerinin açılması için ilk karar 1853 yılında alınmıştır. Meclis-i Maarif-i Umumiyyenin kararı üzerine, 2 Haziran 1853 tarihinde Padişah'ın iradesiyle 25 vilayette peyderpey rüşdiyelerin açılması kararlaştırılmıştır. Fakat bu karar ancak 1856'da uygulamaya konulabilmiştir. ${ }^{9}$ Bundan sonra ise vilayetlerdeki rüşdiye sayısında hızlı bir artış olmuştur. Nitekim 1869 Maarif-i Umumiyye Nizamnamesi yayımlandığı sırada çeşitli vilayetlerde 87 rüşdiye mektebi vardır. ${ }^{10}$

Osmanlı'nın diğer birçok vilayet, sancak ve kazalarında olduğu gibi, bugünkü Şanlıurfa ili ve ilçelerinin önemli bir kısmını içine alan Urfa Sancağında da ilk açılan modern okullar rüşdiye mektepleri olmuştur. Bu okullar sayesinde Urfa bölgesi, bilhassa 19. yüzyılın ikinci yarısında modern ortaokul eğitimi açısından ileri bir düzey yakalamıştır.

Osmanlı modernleşme döneminde Urfa Sancağında açılmış olup, hakkında detaylı bilgiler elde edilebilen başlıca Müslüman rüşdiye mektepleri aşağıdaki şekildedir:

\section{Urfa Mülki Rüşdiye Mektebi}

Maarif Salnamesi kayıtlarında; mektebin, ahali tarafindan 30.000 kuruş masraf yapılarak Urfa şehir merkezinde inşa edildiği ve Sultan II. Abdülhamid Dönemi'nde R. 1306 (1890/1891) yılında açıldığı ifade edilmiştir. ${ }^{11}$ Ancak söz konusu tarih, Osmanlı'nın diğer bölgelerindeki bazı rüşdiyelerde olduğu gibi, muhtemelen mektebin II. Abdülhamid Dönemi'nde daha düzenli bir binada yeniden açılışının kaydıdır. Çünkü yerel kayıtlardan ve resmi yazışmalardan, söz konusu mektebin 1870 'lerde açık olduğu ve bu tarihlerde talebesinin de bulunduğu anlaşılmaktadır. ${ }^{12}$ Mekteb, 1902 yılında Urfa Mülki İdadi Mektebinin açılmass ${ }^{13}$ üzerine muhtemelen bu tarihte idadi

5 Muammer Demirel, “Türk Eğitiminin Modernleşmesinde Rüşdiye Mektepleri”, Türkler, C. 15, Yeni Türkiye Yayınları, Ankara 2002, s. 69-74.

6 Uğur Ünal, Meclis-i Kebir-i Maarif (1869-1922), Türk Tarih Kurumu Yayınları, Ankara 2008, s. 1.

7 BOA, İ. DH, 231/13875, Meclis-i Maarif Reisi Abdülhak Efendi’nin 19 Mart 1851(16 Cemaziyülevvel 1267) tarihli yazısı.

8 Demirel, a. g. m., s. 74.

9 Demirel, a. g. m., s. 76-77.

10 Bayram Kodaman, Abdülhamid Devri Eğitim Sistemi, Türk Tarih Kurumu Yayınları, Ankara 1991, s. 92.

11 Maarif Salnamesi, H. 1317, s. 1138-1139; H. 1318, s. 1276-1277; H. 1319, s. 550-551.

12 Haleb Vilayet Salnamesi, H. 1287, s. 76.

13 SSehnaz Öztürk, Tanzimat'tan Cumhuriyet'e Urfa'da Eğitim, Yayımlanmamış Yüksek Lisans Tezi, Harran Üniversitesi Sosyal Bilimler Enstitüsü, Şanlıurfa 2006, s. 55. 
ile birleştirilmiştir. Çünkü H. 1321 (1903) tarihli Maarif Salnamesi’nde artık Urfa Rüşdiyesinden söz edilmemekte, onun yerine Urfa İdadi Mektebi kaydına yer verilmektedir. Ayrıca, söz konusu idadinin muallim kadrosu arasında bazı rüşdiye muallimlerinin de yer aldığı görülmektedir. ${ }^{14}$

İlk açıldığında muallim-i sani (ikinci muallim) ${ }^{15}$ ile idare edilen Urfa Rüşdiye Mektebine, 1882 yılı başlarında muallim-i evvel (birinci muallim) tayini gündeme gelmiştir. ${ }^{16} \mathrm{Bu}$ tarihte mektebe muallim-i evvel tayin edilip edilmediği veya kimin atandığı bilinmemekle birlikte, 1883 yılı Mayıs'ında Urfa Rüşdiye Mektebi muallim-i evveli istifa ettiğinden ve imtihan zamanı yaklaştığından buraya süratle bir muallim-i evvel atanması yerel makamlarca Maarif Nezaretinden talep edilmiştir. Ancak, Mekâtib-i Rüşdiye İdaresince verilen cevapta; henüz münasip biri bulunamadığından şimdilik muallim-i sani ile idare edilmesi istenmiştir (17 Haziran 1883). ${ }^{17}$ Dolayısıyla mekteb yine muallim-i sani ile idare edilmeye başlanmıştır. Fakat 1885 yılına gelindiğinde, Urfa Rüşdiye Mektebi artık muallim-i evvel ile idare edilmektedir. ${ }^{18}$ Bu durum, talebe adedine bağlı olarak, mektebin son yıllarına kadar aynı şekilde devam etmiştir.

Osmanlı'nın diğer eğitim kurumlarında olduğu gibi, Urfa Rüşdiye Mektebinde de bilhassa muallimlerden kaynaklı olarak eğitimin aksamamasına ve sürekliliğine çok önem verilmiştir. Mesela, Urfa Rüşdiye Mektebi Muallim-i evveli Hacı Abdürrahim Efendi, Urfa Belediye Tabibi’nin raporunu da gerekçe göstererek, rahatsızlığından dolayı İstanbul'a gitmek üzere dört aylık izin talebinde bulunmuştur. Vaziyeti Urfa Liva Meclisince de doğrulanarak, 19 Kasım 1887'den itibaren dört ay izin verilmiştir. Fakat eğitimin aksamaması için yerine vekâleten Maarif Komisyonu Azası Abbas Efendi ${ }^{19}$ tayin edilerek, aynı tarihte göreve başlaması uygun görülmüştür (12 Şubat 1888). ${ }^{20}$

Urfa Rüşdiye Mektebinde görev yapan ve hakkında detaylı bilgiler elde edilen muallim-i evvellerden biri de Gürcistan muhacirlerinden Mehmed Said Efendi olup, 1893 y1lı ortalarında 560 kuruş maaşla bu göreve tayin edilmiş ve dört yıl boyunca burada vazife yapmıştır. Ancak, İhsan Bey’in bu göreve atanması üzerine Urfa Mutasarrıflığına gönderilen 18 Haziran 1897 tarihli bir telgrafta; Mehmed Said Efendi'nin 500 kuruş maaşla, Diyarbekir Vilayeti dâhilinde yer alan Siverek Rüşdiyesi muallim-i evvelliğine tayin olunduğu belirtilerek, seri bir şekilde oraya gitmesi istenmiştir. ${ }^{21}$

Mehmed Said Efendi'den sonra mektepte muallim-i evvel olarak görev alan İhsan Bey ise

14 Maarif Salnamesi, H. 1321, s. 457; Haleb Vilayet Salnamesi, H. 1321, s. 378.

15 Rüşdiye muallimleri, atamaları yapılırken tahsil, kıdem ve maaş durumlarına göre muallim-i evvel, muallim-i sani, muallim-i salis ve hatt (rik’a) muallimi şeklinde sınıflandırılmışlardır. Muallim-i evveller genellikle Darülmuallimin-i Rüşdi mezunu olup merkezden atanırken, muallim-i sani ve salisler ise farklı okullardan mezun olup mahallince imtihanla seçilmişlerdir. Bkz. Hatip Yıldız, "Osmanlı Devleti'nde Mülki (Sivil) Erkek Rüşdiye Muallimlerinin Nitelikleri, Hakları ve Sorumlulukları”, History Studies, A Tribute to Prof. Dr. Şerafettin Turan, Volume 6, Issue 3, April 2014, p. 369-382.

16 BOA, MF. MKT, 75/28.

17 BOA, MF. MKT, 81/15, Maarif Nezaretinden Urfa Sancağı Mutasarrıflı̆̆ına gönderilen 17 Haziran 1883 (11 Şaban 1300) tarihli yazı.

18 BOA, MF. MKT, 85/79.

19 Muallim-i evvellik vekâletinde istihdam edilen Abbas Efendi’nin 13 Eylül 1888 (1 Eylül 1304) ile 14 Kasım 1888 (2 Teşrin-i sani 1304) tarihleri arasında 2 ay 2 günlük olan 578 kuruş maaşının Dersaadet maarif hissesinden mahsup edilerek ödendiği ifade edilmiştir. Bilindiği gibi, vekâleten görev yapanlar, asıl muallimlik maaşının ancak yarısını alabilmektedirler. Bkz. BOA, MF. MKT, 275/73.

20 BOA, MF. MKT, 96/135.

21 BOA, MF. MKT, 359/51, Urfa Rüşdiye Mektebi Muallim-i evveli Mehmed Said Efendi’nin Dâhiliye Nezaretine gönderdiği 16 Haziran 1897 (15 Muharrem 1315) tarihli yazı. 
Ceride-i Askeriyye muharrirlerinden olup, ihtiyaca binaen 1897 yılı başlarında Urfa Rüşdiye Mektebi Muallim-i evvelliğine aylık 1500 kuruş maaşla tayin edilmiştir. Ancak, maarif bütçesinde bu muallimliğin maaşı 550 kuruş olarak belirlendiği için, geriye kalan 950 kuruşun nereden ve nasıl karşılanacağı Dâhiliye ve Maarif nezaretleri arasında tartışma konusu olmuştur. Neticede, söz konusu meblağın Maarif Nezareti bütçesinden karşılanması gerektiği, 21 Haziran 1897 tarihli yazıyla Maarif Nezaretine bildirilmiştir. Bunun sonucunda İhsan Bey’in maaşının 1350 kuruşa çıkarıldığı anlaşılmaktadır. Bu maaşla Urfa Rüşdiyesindeki görevine devam eden İhsan Bey, yaklaşık beş yıl sonra 1902 yılı başlarında, maişetini temin edemediği gerekçesiyle maaşının arttırılması veya başka bir memuriyete tayini hususunda ilgili mercilerden talepte bulunmuştur. Fakat Maarif Nezaretinden alınan cevapta; maaşının, emsali olan birinci derece rüşdiye mektepleri muallimleri maaşından çok yüksek olduğu cihetle, ne maaşının arttırılmasının ve ne de başka bir memuriyete tayinin mümkün olamayacağının kendisine bildirilmesi istenmiştir. ${ }^{22}$

Mektebin ilk yıllarında talebe sayısı 45 civarındadır. Fakat bu rakam Maarif Nezaretince yeterli görülmemiştir. Bu nedenle, Halep Vilayetine gönderilen 9 Mart 1873 tarihli bir yazıda şu hususlara yer verilmiştir:

\begin{abstract}
“Urfa Rüşdiye Mektebi talebelerinin adedinin az olduğu gelen jurnallerin muayenesinden anlaşılmıştır. Urfa'da bulunan sıbyan mekteblerinden rüşdiyeye talebe aldırılması lüzumlu iken, bu hususa itina ve himmet olunmadı̆̆ anlaşılmaktadır. Nezdinizde beyana muhtaç olmadiğı üzere, halkın çocuklarının talimi ve maarif nimetinden bol bol faydalanmaları için memleket mektebleri terakkide görülmek lazım geldiğinden, Urfa sıbyan mekteblerinde rüşdiyeye alınmaya şayan ne kadar çocuk var ise mahalli hükümeti tarafindan peder ve velilerine gerekli teşvikler yapılarak, rüşdiyeye devam ettirilecek talebenin arttırılması gerektiği tarafinızdan muallimlere beyan ve yazllması iktiza edeceği Meclis-i Maariften ifade edildiğinden gereğinin yapılması sizin gayretinize bağlıdır. ”23
\end{abstract}

Ancak bütün bu teşviklere rağmen, tespit edilebildiği kadarıyla, mektebin eğitim süresi boyunca talebe sayısı 76'yı geçememiştir. ${ }^{24}$

Bilindiği gibi, Osmanlı vilayet ve kazalarında bulunan rüşdiye mekteplerinin istediği araçgereçler ile matbu evraklar, ders kitapları ve yardımcı kaynaklar genellikle Maarif Nezareti tarafından posta yoluyla merkezden gönderilmiştir. ${ }^{25} \mathrm{Bu}$ çerçevede, Urfa Rüşdiye Mektebince de bir küre talebinde bulunulmuştur. Fakat istenilen kürenin mevcudu kalmadığ 1 için şimdilik gönderilemediği ifade edilmiştir (7 Mayıs 1872). ${ }^{26}$ Daha sonraki yıllarda yine mektep muallimi tarafından talebeler için resmi yazıyla küre ve Asya haritası talep edilmiştir. Bu sefer de şimdilik yalnız bir adet haritanın postaya verildiği, kürenin de imal edilmekte olduğu ve bitiminde gönderileceği belirtilmiştir (25 Kasım 1874). ${ }^{27}$

22 BOA, MF. MKT, 359/51; BEO, 892/66891; BEO, 959/71916; DH. MKT, 2081/23; BEO, 967/72480; DH. MKT, 2574/72; DH. MKT, 2591/114.

23 BOA, MF. MKT, 9/89, Maarif Nezaretinden Haleb Vilayetine gönderilen 9 Mart 1873 (9 Muharrem 1290) tarihli yazı.

24 Osmanlı Devlet Salnamesi, H. 1300, s. 211.

25 Bahri Ata, "Osmanlı İmparatorluğu Döneminde Bir Ders Araç ve Gereçleri Lojistik Merkezi: Maarif Kütüphanesi (1872-1895)", Tarihin Peşinde: Uluslararası Tarih ve Sosyal Araştırmalar Dergisi, 1, (2009), s. 29-31.

26 BOA, MF. MKT, $1 / 5$.

27 BOA, MF. MKT, 21/92, Maarif Nezaretinden Haleb Vilayetine gönderilen 25 Kasım 1874 (15 Şevval 1291) tarihli yazı. 
1870-1902 yılları arasında aktif olduğu tespit edilebilen mektebin eğitim ve yardımcı personel kadrosu ile talebe adedinin yıllara göre dağılımı aşağıdaki şekildedir:

Tablo 1. Urfa Mülki Rüşdiye Mektebi Personel ve Talebe Çizelgesi

\begin{tabular}{|c|c|c|c|c|c|c|}
\hline YIL & $\begin{array}{c}\text { BİRINCI் } \\
\text { MUALLIMM }\end{array}$ & $\begin{array}{c}\text { İKİNCI் } \\
\text { MUALLİM }\end{array}$ & $\begin{array}{l}\text { ÜÇÜNCÜ } \\
\text { MUALLIM }\end{array}$ & $\begin{array}{l}\text { HATT/RİKA } \\
\text { MUALLİMİ }\end{array}$ & $\begin{array}{c}\text { BEVVAB/ } \\
\text { HADEME/ } \\
\text { MUBASSIR }\end{array}$ & $\begin{array}{c}\text { TALEBE } \\
\text { ADEDI் }\end{array}$ \\
\hline $1870^{1}$ & - & - & - & - & - & - \\
\hline $1871^{2}$ & - & $\begin{array}{l}\text { Muallim-i sani ile } \\
\text { idare edilmektedir. }\end{array}$ & - & - & - & - \\
\hline $1872^{3}$ & - & $\begin{array}{l}\text { Muallim-i sani ile } \\
\text { idare edilmektedir. }\end{array}$ & - & - & - & 45 \\
\hline $1873^{4}$ & - & $\begin{array}{l}\text { Muallim-i sani ile } \\
\text { idare edilmektedir. }\end{array}$ & - & - & - & 45 \\
\hline $1874^{5}$ & - & $\begin{array}{l}\text { Muallim-i sani ile } \\
\text { idare edilmektedir. }\end{array}$ & - & - & - & 53 \\
\hline $1875^{6}$ & - & $\begin{array}{l}\text { Muallim-i sani ile } \\
\text { idare edilmektedir. }\end{array}$ & - & - & - & 35 \\
\hline $1876^{7}$ & - & $\begin{array}{l}\text { Muallim-i sani ile } \\
\text { idare edilmektedir. }\end{array}$ & - & - & - & 35 \\
\hline $1877^{8}$ & - & $\begin{array}{l}\text { Muallim-i sani ile } \\
\text { idare edilmektedir. }\end{array}$ & - & - & - & 40 \\
\hline $1878^{9}$ & - & - & - & - & - & - \\
\hline $1879^{10}$ & - & - & - & - & - & - \\
\hline $1880^{11}$ & - & - & - & - & - & - \\
\hline $1881^{12}$ & - & Reşid Efendi & - & - & - & 33 \\
\hline $1882^{13}$ & - & Reşid Efendi & - & - & - & 17 \\
\hline $1883^{14}$ & - & - & - & - & - & $74 / 76$ \\
\hline $1884^{15}$ & - & - & - & - & - & 70 \\
\hline $1885^{16}$ & Abdürrahim Ef. & - & - & - & - & $74 / 70$ \\
\hline $1886^{17}$ & Abdürrahim Ef. & - & - & - & - & $74 / 72$ \\
\hline $1887^{18}$ & $\begin{array}{l}\text { Abdürrahim } \\
\text { Efendi/Abbas Ef. }\end{array}$ & - & - & - & - & 70 \\
\hline $1888^{19}$ & $\begin{array}{l}\text { Abdürrahim } \\
\text { Efendi/Abbas Ef. }\end{array}$ & - & - & - & - & $74 / 59$ \\
\hline $1889^{20}$ & - & - & - & - & - & 74 \\
\hline $1890^{21}$ & Halil Efendi & Abdurrahman Ef. & - & - & Ramazan Ef. & - \\
\hline $1891^{22}$ & Halil Efendi & Abdurrahman Ef. & - & - & Mehmed Ağa & - \\
\hline $1892^{23}$ & Halil Efendi & Abdurrahman Ef. & - & - & Hasan Ağa & - \\
\hline $1893^{24}$ & $\begin{array}{l}\text { Hacı Halil Kamil } \\
\text { Efendi }\end{array}$ & $\begin{array}{c}\text { Abdurrahman } \\
\text { Efendi }\end{array}$ & - & - & Mustafa Ağa & - \\
\hline $1894^{25}$ & $\begin{array}{l}\text { Mehmed Said } \\
\text { Efendi }\end{array}$ & $\begin{array}{c}\text { Abdurrahman } \\
\text { Efendi }\end{array}$ & - & $\begin{array}{c}\text { Mehmed Şerif } \\
\text { Efendi }\end{array}$ & Hasan Ağa & - \\
\hline $1895^{26}$ & $\begin{array}{l}\text { Mehmed Said } \\
\text { Efendi }\end{array}$ & $\begin{array}{c}\text { Abdurrahman } \\
\text { Efendi }\end{array}$ & - & $\begin{array}{l}\text { Mehmed Şerif } \\
\text { Efendi }\end{array}$ & Hasan Ağa & - \\
\hline $1896^{27}$ & $\begin{array}{l}\text { Mehmed Said } \\
\text { Efendi }\end{array}$ & $\begin{array}{c}\text { Abdurrahman } \\
\text { Efendi }\end{array}$ & - & $\begin{array}{c}\text { Mehmed Şerif } \\
\text { Efendi }\end{array}$ & Hasan Ağa & 67 \\
\hline $1897^{28}$ & $\begin{array}{l}\text { Mehmed Said } \\
\text { Efendi }\end{array}$ & $\begin{array}{l}\text { Abdurrahman } \\
\text { Efendi }\end{array}$ & - & $\begin{array}{c}\text { Mehmed Şerif } \\
\text { Efendi }\end{array}$ & Hasan Ağa & 55 \\
\hline
\end{tabular}




\begin{tabular}{|c|l|c|c|c|c|c|}
\hline $1898^{29}$ & İhsan Bey & $\begin{array}{c}\text { Abdurrahman } \\
\text { Efendi }\end{array}$ & - & $\begin{array}{c}\text { Mehmed Şerif } \\
\text { Efendi }\end{array}$ & Hasan Ăga & 47 \\
\hline $1899^{30}$ & İhsan Bey & $\begin{array}{c}\text { Abdurrahman } \\
\text { Efendi }\end{array}$ & - & $\begin{array}{c}\text { Mehmed Şerif } \\
\text { Efendi }\end{array}$ & Hasan Ağa & 58 \\
\hline $1900^{31}$ & İhsan Bey & $\begin{array}{c}\text { Abdurrahman } \\
\text { Efendi }\end{array}$ & - & $\begin{array}{c}\text { Mehmed Şerif } \\
\text { Efendi }\end{array}$ & 1 & 60 \\
\hline $1901^{32}$ & İhsan Bey & $\begin{array}{c}\text { Abdurrahman } \\
\text { Efendi }\end{array}$ & - & $\begin{array}{c}\text { Mehmed Şerif } \\
\text { Efendi }\end{array}$ & 1 & 60 \\
\hline $1902^{33}$ & İhsan Bey & $\begin{array}{c}\text { Abdurrahman } \\
\text { Efendi }\end{array}$ & - & $\begin{array}{c}\text { Mehmed Şerif } \\
\text { Efendi }\end{array}$ & - & - \\
\hline
\end{tabular}

\section{Birecik Mülki Rüşdiye Mektebi}

Maarif Salnamesi kayıtlarında; mektebin, ahali tarafından Birecik kazası merkezinde inşa edilerek, Sultan II. Abdülhamid Dönemi’nde açıldığı ifade edilmiştir. ${ }^{28}$ Fakat bu kayıt sehven düşülmüş olup, mektebin açılışı muhtemelen 1869-1870 öğretim yılı başlarında gerçekleştirilmiştir. ${ }^{29}$

İlk zamanlarda muallim-i sani ile eğitime başlayan Birecik Rüşdiye Mektebi, talebe sayısının artışına bağlı olarak daha sonraki yıllarda muallim-i evvel, muallim-i sani ve rika muallimleri ile bir bevvab tarafından idare edilmiştir. Mektebin talebe adedi ilk yıllarda 30 civarında iken, daha sonraki dönemlerde bazen 89'a kadar çıkmıştır. ${ }^{30}$

Diğer mekteplerde olduğu gibi, Birecik Rüşdiye Mektebinde de muallim yokluğundan kaynaklanabilecek eğitim aksamalarının yaşanmamasına özen gösterilmiştir. Mesela mektebin muallim-i sanisi Salih Hayali Efendi, eğitim-öğretim meşgalesiyle usanmış olan zihinlerin istirahatı için önemli olan ve buna binaen ders günlerinden ayrılan tatil zamanının yaklaşmasından dolayı, imtihanı tamamladıktan sonra hava değişimine giderek tatilden çok istifade etmek ve Dersaadet'te hususi bir işini de görmek üzere tatile denk gelecek Haziran başından (13 Haziran 1896) itibaren iki ay kadar izin talebinde bulunmuştur (7 Mayıs 1896). ${ }^{31}$ Bunun üzerine, Mekatib-i Rüşdiye İdaresince atama kayıtları ile ilgili yapılan incelemeler sonucunda; adı geçen muallimin R. 1309 (1893/1894) yılında buradaki görevine tayin edildiği ve şimdiye kadar izin almadığı anlaşılmış olmasına rağmen, eğitim-öğretime başlandığı zaman memuriyet vazifesinin başında bulunmak ve aksi takdirde istifa etmiş sayılmak şartıyla, tatil günleri olan bir ay müddetle izinli sayılması uygun görülmüştür (2 Haziran 1896). ${ }^{32}$ Görüldüğü gibi, eğitim-öğretimin ve sınavların aksamaması için iki aylık izin talebi bir aya indirilmiştir.

Birecik ve Rumkale rüşdiyelerinin ihtiyaç duyduğu kitap ve risaleler de, tıpkı diğer rüşdiyelerde olduğu gibi, Maarif Nezaretince posta yoluyla gönderilmiştir. Nitekim daha önce bu mektepler için gönderilen kitapların bir miktarının Urfa Rüşdiye Mektebine aktarıldığı anlaşılmış; bu nedenle, sözü edilen mektepler için lüzumlu olan kitap ve risalelerin, fiyat defteri ile birlikte tekrar yollandığı ifade edilmiştir (28 Temmuz 1872). Bu defa gönderilen kitap, risale ve haritaların

28 Maarif Salnamesi, H. 1318, s. 1276-1277; H. 1319, s. 550-551.

29 BOA, ŞD, 2212/49.

30 Haleb Vilayeti Salnamesi, H. 1289, s. 73; Osmanl1 Devlet Salnamesi, H. 1289, s. 240; H. 1303 , s. 338.

31 BOA, MF. MKT, 322/34, Birecik Rüşdiye Mektebi Muallim-i sanisi Salih Hayali Efendi tarafından Haleb Vilayeti Maarif Müdürlüğüne gönderilen 7 Mayıs 1896 (25 Nisan 1312) tarihli yazı.

32 BOA, MF. MKT, 322/34, Mekatib-i Rüşdiye İdaresinin 2 Haziran 1896 (21 Mayıs 1312) tarihli yazısı. 
isim ve adedi aşağıdaki gibidir: ${ }^{33}$

Tablo 2. Birecik ve Rumkale Rüşdiyelerine Gönderilen Bazı Kitap, Risale ve Haritalar

\begin{tabular}{|c|l|c|}
\hline $\begin{array}{c}\text { SIRA } \\
\text { NO }\end{array}$ & KITAP/RISALE/HARITAADI & $\begin{array}{c}\text { KITAP/RISALE/ } \\
\text { HARITAADEDI }\end{array}$ \\
\hline 1 & Vezaif-i Etfal & 30 \\
\hline 2 & Risale-i İlm-i Hesab & 40 \\
\hline 3 & Muhtasar Münşeat & 40 \\
\hline 4 & Mi'yarü'l-Kelam & 40 \\
\hline 5 & Talim-i Farisi & 20 \\
\hline 6 & Gülistan & 40 \\
\hline 7 & Avrupa Haritası & 1 \\
\hline 8 & Afrika Haritası & 20 \\
\hline 9 & Bina & 20 \\
\hline 10 & Fezleke-i Tarih-i Osmanî & $\mathbf{2 5 2}$ \\
\hline & & \\
\hline
\end{tabular}

1869-1910 yılları arasında aktif olduğu tespit edilebilen mektebin eğitim ve yardımcı personel kadrosu ile talebe adedinin yıllara göre dağılımı aşağıdaki şekildedir:

Tablo 3. Birecik Mülki Rüşdiye Mektebi Personel ve Talebe Çizelgesi

\begin{tabular}{|c|c|c|c|c|c|c|}
\hline YIL & $\begin{array}{c}\text { BİRİNCI } \\
\text { MUALLİM }\end{array}$ & $\begin{array}{c}\text { İKİNCİ } \\
\text { MUALLİM }\end{array}$ & $\begin{array}{c}\text { ÜÇÜNCÜ } \\
\text { MUALLİM }\end{array}$ & $\begin{array}{l}\text { HATT/RİKA } \\
\text { MUALLİMI }\end{array}$ & $\begin{array}{c}\text { BEVVAB/ } \\
\text { HADEME/ } \\
\text { MUBASSIR }\end{array}$ & $\begin{array}{c}\text { TALEBE } \\
\text { ADEDI் }\end{array}$ \\
\hline $1869^{34}$ & - & - & - & - & - & - \\
\hline $1870^{35}$ & - & - & - & - & - & - \\
\hline $1871^{36}$ & - & - & - & - & - & - \\
\hline $1872^{37}$ & - & $\begin{array}{l}\text { Muallim-i sani ile } \\
\text { idare olunmaktadır. }\end{array}$ & - & - & - & 28 \\
\hline $1873^{38}$ & - & $\begin{array}{l}\text { Muallim-i sani ile } \\
\text { idare olunmaktadır. }\end{array}$ & - & - & - & 28 \\
\hline $1874^{39}$ & - & $\begin{array}{l}\text { Muallim-i sani ile } \\
\text { idare olunmaktadır. }\end{array}$ & - & - & - & 26 \\
\hline $1875^{40}$ & - & $\begin{array}{l}\text { Muallim-i sani ile } \\
\text { idare olunmaktadır. }\end{array}$ & - & - & - & 36 \\
\hline $1876^{41}$ & - & $\begin{array}{l}\text { Muallim-i sani ile } \\
\text { idare olunmaktadır }\end{array}$ & - & - & - & 36 \\
\hline $1877^{42}$ & - & $\begin{array}{l}\text { Muallim-i sani ile } \\
\text { idare olunmaktadır }\end{array}$ & - & - & - & 42 \\
\hline $1878^{43}$ & - & - & - & - & - & \\
\hline $1879^{44}$ & - & - & - & - & - & \\
\hline $1880^{45}$ & - & - & - & - & - & - \\
\hline $1881^{46}$ & - & Kemal Efendi & - & - & - & 20 \\
\hline $1882^{47}$ & - & Kemal Efendi & - & - & - & 20 \\
\hline
\end{tabular}




\begin{tabular}{|c|c|c|c|c|c|c|}
\hline $1883^{48}$ & - & - & - & - & - & $16 / 45$ \\
\hline $1884^{49}$ & - & - & - & - & - & 78 \\
\hline $1885^{50}$ & - & - & - & - & - & 87 \\
\hline $1886^{51}$ & - & - & - & - & - & $87 / 89$ \\
\hline $1887^{52}$ & - & - & - & - & - & 131 \\
\hline $1888^{53}$ & - & - & - & - & - & $87 / 86$ \\
\hline $1889^{54}$ & - & - & - & - & - & 87 \\
\hline $1890^{55}$ & $\begin{array}{l}\text { Hasan Remzi } \\
\text { Efendi }\end{array}$ & Hacı Sadık Efendi & - & $\begin{array}{l}\text { Hafiz Mustafa } \\
\text { Efendi }\end{array}$ & $\begin{array}{c}\text { İbrahim } \\
\text { Efendi }\end{array}$ & - \\
\hline $1891^{56}$ & $\begin{array}{l}\text { Mahmud Lami' } \\
\text { Efendi }\end{array}$ & Hacı Sadık Efendi & - & $\begin{array}{c}\text { Hafiz Mustafa } \\
\text { Efendi }\end{array}$ & $\begin{array}{c}\text { Hac1 Mehmed } \\
\text { Ağa }\end{array}$ & - \\
\hline $1892^{57}$ & $\begin{array}{l}\text { Mahmud Lami' } \\
\text { Efendi }^{58}\end{array}$ & Hacı Sadık Efendi & - & $\begin{array}{c}\text { Mustafa Nef'i } \\
\text { Efendi }\end{array}$ & $\begin{array}{c}\text { Hac1 Mehmed } \\
\text { Ağa }\end{array}$ & - \\
\hline $1894^{59}$ & $\begin{array}{l}\text { Hasan Remzi } \\
\text { Efendi }\end{array}$ & Salih Hayali Efendi & - & $\begin{array}{c}\text { Mustafa Nef'i } \\
\text { Efendi }\end{array}$ & $\begin{array}{c}\text { Hac1 Mehmed } \\
\text { Ağa }\end{array}$ & 55 \\
\hline $1895^{60}$ & $\begin{array}{l}\text { Hasan Remzi } \\
\text { Efendi }\end{array}$ & Salih Hayali Efendi & - & $\begin{array}{c}\text { Mustafa Nef'i } \\
\text { Efendi }\end{array}$ & $\begin{array}{c}\text { Hacs Mehmed } \\
\text { Ef. }\end{array}$ & - \\
\hline $1896^{61}$ & $\begin{array}{l}\text { Hasan Remzi } \\
\text { Efendi }\end{array}$ & Salih Hayali Efendi & - & $\begin{array}{c}\text { Mustafa Nef'i } \\
\text { Efendi }\end{array}$ & $\begin{array}{c}\text { Mükerrem } \\
\text { Ağa }\end{array}$ & - \\
\hline $1897^{62}$ & $\begin{array}{l}\text { Hasan Remzi } \\
\text { Efendi }\end{array}$ & Salih Hayali Efendi & - & $\begin{array}{c}\text { Mustafa Nef'i } \\
\text { Efendi }\end{array}$ & $\begin{array}{c}\text { Hac1 Mehmed } \\
\text { Ağa }\end{array}$ & 55 \\
\hline $1898^{63}$ & $\begin{array}{l}\text { Hasan Remzi } \\
\text { Efendi }\end{array}$ & Salih Hayali Efendi & - & $\begin{array}{c}\text { Mustafa Nef'i } \\
\text { Efendi }\end{array}$ & $\begin{array}{c}\text { Hac1 Mehmed } \\
\text { Ağa }\end{array}$ & 55 \\
\hline $1899^{64}$ & $\begin{array}{l}\text { Hasan Remzi } \\
\text { Efendi }\end{array}$ & Salih Hayali Efendi & - & $\begin{array}{c}\text { Mustafa Nef'i } \\
\text { Efendi }\end{array}$ & $\begin{array}{c}\text { Hac1 Mehmed } \\
\text { Ağa }\end{array}$ & $54 / 55$ \\
\hline $1900^{65}$ & $\begin{array}{l}\text { Eşref Efendi } \\
\text { (Vekil) }\end{array}$ & Münhaldır & - & $\begin{array}{c}\text { Mustafa Nef'i } \\
\text { Efendi }\end{array}$ & 1 & 55 \\
\hline $1901^{66}$ & $\begin{array}{l}\text { Mustafa Sabri } \\
\text { Efendi }\end{array}$ & Salih Hayali Efendi & - & $\begin{array}{c}\text { Mustafa Nef'i } \\
\text { Efendi }\end{array}$ & 1 & 57 \\
\hline $1902^{67}$ & $\begin{array}{l}\text { Mustafa Sabri } \\
\text { Efendi }\end{array}$ & Salih Hayali Efendi & - & $\begin{array}{c}\text { Mustafa Nef'i } \\
\text { Efendi }\end{array}$ & - & 62 \\
\hline $1903^{68}$ & $\begin{array}{l}\text { Mustafa Sabri } \\
\text { Efendi }\end{array}$ & Salih Hayali Efendi & - & $\begin{array}{c}\text { Mustafa Nef'i } \\
\text { Efendi }\end{array}$ & 1 & $60 / 70$ \\
\hline $1904^{69}$ & $\begin{array}{l}\text { Mustafa Sabri } \\
\text { Efendi }\end{array}$ & Salih Hayali Efendi & - & $\begin{array}{c}\text { Musa Kazım } \\
\text { Efendi }\end{array}$ & - & 72 \\
\hline $1905^{70}$ & $\begin{array}{l}\text { Mustafa Sabri } \\
\text { Efendi }\end{array}$ & Salih Hayali Efendi & - & $\begin{array}{l}\text { Mehmed Vefa } \\
\text { Efendi }\end{array}$ & - & 80 \\
\hline $1906^{71}$ & $\begin{array}{l}\text { Mustafa Sabri } \\
\text { Efendi }\end{array}$ & Salih Hayali Efendi & - & $\begin{array}{c}\text { Mehmed Vefa } \\
\text { Efendi }\end{array}$ & - & 80 \\
\hline $1907^{72}$ & - & Salih Hayali Efendi & - & - & - & - \\
\hline $1908^{73}$ & $\begin{array}{l}\text { Mustafa Sabri } \\
\text { Efendi }\end{array}$ & Salih Hayali Efendi & - & $\begin{array}{c}\text { Salih Hayali } \\
\text { Efendi }\end{array}$ & - & 43 \\
\hline $1910^{74}$ & Mümtaz Efendi & - & - & - & - & - \\
\hline
\end{tabular}




\section{Rumkale (Halfeti) Mülki Rüşdiye Mektebi}

Maarif Salnamesi kayıtlarında; mektebin, ahali tarafından Rumkale kazası merkezinde inşa edilerek, Sultan II. Abdülhamid Dönemi’nde açıldığ 1 ifade edilmiştir. ${ }^{34}$ Fakat bu kayıt da sehven düşülmüş olup, mektebin açılışı muhtemelen 1870'lerde gerçekleştirilmiştir. ${ }^{35}$

Açıldığı günden beri yaklaşık 26 yıl boyunca muallim-i sanilikle idare edilen mektebin talebe sayısı, 1884 yılında buraya muallim-i sani olarak tayin edilen Abdülkadir Efendi zamanında gösterilen gayret sonucunda, R. 1298 (1882/1883) senesine nispeten üçte iki oranında artış göstererek 70'e çıkmıştır. Bu nedenle dar gelen mevcut rüşdiye binası talebeye yetmemiş ve mektep yeni inşa olunan başka bir binaya nakledilmiştir (22 Mart 1896). ${ }^{36}$ Fakat talebe sayısındaki artışa ve muallimin sair meşguliyetlerine rağmen, mektebin tek bir muallim-i sani ile idaresine uzun yıllar devam edilmiştir.

Maarif Nezaretinin 29 Mayıs 1895 tarihli telgrafnamesinde; Osmanlı'daki rüşdiye mekteplerinin üç derece üzerine tertip edildiği ve muallim maaşlarının da buna göre belirlendiği; fakat yapılan yeni düzenlemelerin bundan sonra mekteplerde muallim boşluğu oluştukça peyderpey uygulamaya konulacağı ifade edilmiştir. Bunun üzerine harekete geçen Haleb Vilayeti Maarif Müdürlüğüne göre; Rumkale Rüşdiyesi öteden beri bir muallim-i sani idaresinde kalmış olup, bu muallimlerden program dairesinde tedrisat ve terakki beklemek muhali temenni kabilindendir. Ayrıca, söz konusu düzenlemeyle, istifa eden kişilerin maaşlarının bahsi geçen yerin muallimliği için tahsis edilmesi uygun olup, bu miktar maaşla da Darülmuallimin-i Rüşdiye şahadetnamelilerinden yetenekli bir muallimin tayin ve gönderilmesi mümkündür. $\mathrm{Bu}$ nedenle Rumkale Rüşdiyesi muallimliğine, münasip ve muktedir bir muallimin tayin ve gönderilmesine müsaade edilmelidir (28 Mayıs 1896). ${ }^{37}$

Haleb Vilayeti Maarif Müdürlüğünün sözü edilen bu önerisini değerlendiren Mekatib-i Rüşdiye İdaresi şöyle bir karara varmıştır:

“...Darülmualliminde tahsil etmeyerek mahallince seçilen muallim-i sanilerle idare olunan rüşdiye mekteblerinin vücudundan istifade edilemeyeceği muhakkak olduğu cihetle, bu mekteblere Darülmuallimin şahadetnamelilerinden birer muallim tayin buyrulmasındaki lüzum aşikârdır. Bununla beraber, yeni düzenlemelerin mekteblerde boşluk oluşmasına bağlı olması ve kademeli olarak uygulamaya konulması hakkındaki karar, bir takım muallimlerin açıkta kalarak mağdur olmalarına neden olmaktadır. Ayrıca, bu düzenlemelerle tahsisat-ı atika devrettirilmiş, yani mekteblerin bazısından kesilen tahsisat diğerlerine eklenmek suretiyle idare-i maslahat edilmiştir. Bu münasebetle, muallim-i sani idaresinde bulunan mekteblerin bir defada muallim-i evvel idaresine birakılması halinde artacak masrafa karşılık bulunamayarak, maaşların ödenememesi yüzünden şikâyetlerin olmasına mahal kalmaması gerekir. Şu halde bahsi geçen mektebe şimdiden muallim-i evvel tayini mümkün olamayacağının; ancak muallimin vazifesini yapmada tamamen iktidarsızlığı, rehavet ve tembelliği tahakkuk ederse, bildirilmesi halinde, azl ve tebdil ile yerine yeni düzenlemeler gereğince muallim-i evvel tayin edilmesi zaruri bulunduğunun cevaben müdürlüğe bildirilmesi

34 Maarif Salnamesi, H. 1318, s. 1276-1277; H. 1319, s. 550-551.

35 Osmanlı Devlet Salnamesi, H. 1287, s.127.

36 BOA, MF. MKT, 315/48, Abdülkadir Efendi’nin Haleb Vilayeti Maarif Müdürlüğüne gönderdiği 22 Mart 1896 (7 Şevval 1313) tarihli yazı.

37 BOA, MF. MKT, 324/44, Haleb Vilayeti Maarif Müdürlüğünden Maarif Nezaretine gönderilen 28 Mayıs 1896 (15 Zilhicce 1313) tarihli yazı. 
uygundur (17 Haziran 1896)." 38

Maarif Nezaretinin bu olumsuz cevabına rağmen, Rumkale Kazası İdare Meclisi, hem Rumkale Rüşdiye Mektebinin düzeyini muallim-i sanilikten muallim-i evvellik sınıfına yükseltmek ve hem de uzun yıllar burada muallim-i sani olarak başarılı hizmetlerde bulunan Abdülkadir Efendi'nin muallim-i evvel olma isteğini yerine getirmek için yeniden talepte bulunmuştur (25 Temmuz 1896). ${ }^{39}$ Ancak, Mekatib-i Rüşdiye İdaresince 7 Eylül 1896 tarihli yazıyla yapılan değerlendirme sonucunda yine olumsuz bir cevap verilmiştir. ${ }^{40}$ Bütün bu olumsuzluklara rağmen, Abdülkadir Efendi'nin daha sonraki yıllarda burada muallim-i evvel vekili olarak çalışmaya başlamış olması, bu mektebin düzeyinin muallim-i evvelliğe yükseltildiğini göstermektedir. ${ }^{41}$

Rumkale Rüşdiye Mektebinde yaklaşık 13 y1lı muallim-i sanilik ve 2 y1lı da muallim-i evvel vekilliği olmak üzere toplamda 15 yıl görev yapan Abdülkadir Efendi hakkında elde dilen bilgilerin bir arada verilmesi önem arz etmektedir. Abdülkadir Efendi, R. 1290 (1874/1875)'dan 1896 yılı başlarına kadar toplamda 20 seneden fazla, Haleb Vilayeti dâhilinde bulunan Deyr ve Urfa sancakları ile Birecik ve Rumkale kazaları rüşdiye mekteblerinde muallim-i sani olarak bulunmuş ve bu süre zarfında vatan evladının tahsil ve talimine ciddi bir şekilde çalışmıştır. Bilhassa Rumkale Rüşdiye Mektebinde görev aldığ1 1884 yılından itibaren, R. 1298 (1882/1883) senesine nispetle, mektebin talebe adedini yaklaşık üçte iki oranında arttırmıştır. Ayrıca, mevcut mektep binasının yeterli gelmemesi üzerine yeni bir bina inşa ettirerek rüşdiyeyi buraya naklettirmiştir. Abdülkadir Efendi, bahsi geçen bütün bu hizmetlerinden dolayı, Padişah tarafindan taltif edilmek suretiyle diğer meslektaşları gibi sevindirilmek istemiştir (22 Mart 1896). Ancak, Maarif Nezaretince yapılan değerlendirme sonucunda; rüşdiye mektepleri muallim-i sanilerinin "rüus" ilmiye rütbesiyle taltiflerinin usule aykırı olduğu belirtilerek, teklifi uygun görülmemiştir. ${ }^{42}$

Taltif konusunda istediğini elde edemeyen Abdülkadir Efendi, bu defa da ailesinin kalabalık olmasından dolayı muallim-i sanilik maaşıyla geçimini sağlamada zorluk çekmekte olduğunu ve buna binaen, muallm-i sanisi bulunduğu Rumkale Rüşdiye Mektebinin düzeyinin muallim-i evvellik sınıfına terfi ettirilerek, kendisinin de bu muallimliğe tayin edilmesini istemiştir. Bu da olmadığ1 takdirde, Haleb Vilayeti dâhilinde bulanan Urfa, Kilis, Birecik, Nizib ve Rakka kazalarından birinin rüşdiye mektebi muallim-i evvelliğine terfi ettirilmesi talebinde bulunmuştur. Bu talep Rumkale Kazası İdare Meclisince de yerinde görülerek, Abdülkadir Efendi'nin 12 seneden beri mektebin terakkisi yolunda büyük çaba sarf ettiği ve bu sayede talebenin adedinin günbegün arttı̆̆ 1 beyan edilmiştir. Fakat bu talebelerin eğitim-öğretimlerinin yanı sıra, vazifesine ilave edilen resmi yazışma ve çizelgeler hazırlama görevlerinin bir muallim tarafından yapılmasının çok zor olduğu vurgulanmıştır. Bu nedenle, söz konusu mektebin sınıfının bir derece daha terfii ve muallim-i evvelliğine Abdülkadir Efendi’nin tayin edilmesi halinde, mektebin bir kat daha terakki edeceği ifade edilmiştir (25 Temmuz 1896). ${ }^{43}$ Ancak, Mekatib-i Rüşdiye İdaresi, Abdülkadir

38 BOA, MF. MKT, 324/44, Mekatib-i Rüşdiye İdaresinin 17 Haziran 1896 (5 Haziran 1312) tarihli yazısı.

39 BOA, MF. MKT, 335/34, Rumkale Kazası İdare Meclisinin 25 Temmuz 1896 (14 Safer 1314) tarihli mazbatas1.

40 BOA, MF. MKT, 335/34; MF. MKT, 338/3.

41 BOA, MF. MKT, 480/7, Haleb Vilayeti Maarif Müdürlüğünden Maarif Nezaretine gönderilen 15 Eylül 1899 (9 Cemaziyülevvel 1317) tarihli yazı.

42 BOA, MF. MKT, 315/48.

43 BOA, MF. MKT, 335/34. 
Efendi'nin mahallince seçilen muallim-i sanilerden olup Dârülmuallimîn şahadetnamesine sahip olmadığını, taşra rüşdiye mektepleri muallim-i evvelliklerinin ise Dârülmuallimîn mezunlarına münhasır bulunduğunu belirterek, söz konusu talebin yerine getirilmesinin mümkün olmadığına karar vermiştir (7 Eylül 1896/26 Ağustos 1312). Buna rağmen daha sonraki y1llarda Abdülkadir Efendi'nin aynı okula muallim-i evvel vekili olarak atandığı anlaşılmaktadır. ${ }^{44}$ Fakat Abdülkadir Efendi, muallim-i evvel olarak çalışmayı şiddetle istediği halde, çok kısa bir süre sonra müftülük görevine geçtiğinden, uzun yıllar çalıştığı mektepten 1 Ağustos 1899 tarihinde ayrılmıştır. ${ }^{45}$

Rumkale Rüşdiye Mektebi muallim-i evvelliği vekâletinden istifa ettiği, 23 Şubat 1899 tarihli yazıyla arz olunan Abdülkadir Efendi'nin yerine, bu kazanın ulemasından olup evrakların ekinde biyografisi takdim edilen Mustafa Tevfik Efendi muallim-i evvel vekili olarak tayin edilmiştir. Tatil dönemi olmasına rağmen mektep boş bırakılmamış, Abdülkadir Efendi’nin görevden ayrıldığının ertesi günü, yani 2 Ağustos 1899 tarihinde Mustafa Tevfik Efendi resmen göreve başlatılmıştır. ${ }^{46}$ Bu durum, Meclis-i Kebir-i Maarif tarafından da tasdik edilmiştir. ${ }^{47}$

1870-1908 yılları arasında aktif olduğu tespit edilebilen mektebin eğitim ve yardımcı personel kadrosu ile talebe adedinin yıllara göre dağılımı aşağıdaki şekildedir:

Tablo 4. Rumkale Mülki Rüşdiye Mektebi Personel ve Talebe Çizelgesi

\begin{tabular}{|c|l|c|c|c|c|c|}
\hline YIL & $\begin{array}{c}\text { BİRINCI } \\
\text { MUALLIM }\end{array}$ & İKİNCI MUALLIM & $\begin{array}{c}\text { ÜC̈ÜNCÜ } \\
\text { MUALLIM }\end{array}$ & $\begin{array}{c}\text { HATT/RİKA } \\
\text { MUALLIMI }\end{array}$ & $\begin{array}{c}\text { BEVVAB/ } \\
\text { HADEME/ } \\
\text { MUBASSIR }\end{array}$ & $\begin{array}{c}\text { TALEBE } \\
\text { ADEDİ }\end{array}$ \\
\hline $1870^{75}$ & - & - & - & - & - & - \\
\hline $1871^{76}$ & - & - & - & - & - & - \\
\hline $1872^{77}$ & - & - & - & - & 32 \\
\hline $1873^{78}$ & - & $\begin{array}{c}\text { Muallim-i sani ile } \\
\text { idare edilmektedir. }\end{array}$ & - & - & - & 32 \\
\hline $1874^{79}$ & - & $\begin{array}{c}\text { Muallim-i sani ile } \\
\text { idare edilmektedir. }\end{array}$ & - & - & - & 34 \\
\hline $1875^{80}$ & - & $\begin{array}{c}\text { Muallim-i sani ile } \\
\text { idare edilmektedir. }\end{array}$ & - & - & - & 29 \\
\hline $1876^{81}$ & - & $\begin{array}{c}\text { Muallim-i sani ile } \\
\text { idare edilmektedir. }\end{array}$ & - & - & - & 29 \\
\hline $1877^{82}$ & - & $\begin{array}{c}\text { Muallim-i sani ile } \\
\text { idare edilmektedir. }\end{array}$ & - & - & - & 35 \\
\hline $1878^{83}$ & - & $\begin{array}{c}\text { Muallim-i sani ile } \\
\text { idare edilmektedir. }\end{array}$ & - & - & - & - \\
\hline $1879^{84}$ & - & - & - & - & - & - \\
\hline $1880^{85}$ & - & - & - & - & - & - \\
\hline $1881^{86}$ & - & - & - & - & - & 22 \\
\hline $1882^{87}$ & - & Müslüm Efendi & - & - & - & 23 \\
\hline
\end{tabular}

44 BOA, MF. MKT, 335/34; MF. MKT, 338/3; MF. MKT, 480/7

45 BOA, MF. MKT, 480/7.

46 BOA, MF. MKT, 480/7, Haleb Vilayeti Maarif Müdürlüğünden Maarif Nezaretine gönderilen 15 Eylül 1899 (9 Cemaziyülevvel 1317) tarihli yazı.

47 BOA, MF. MKT, 480/7. 


\begin{tabular}{|c|c|c|c|c|c|c|}
\hline $1883^{88}$ & - & - & - & - & - & $41 / 40$ \\
\hline $1884^{89}$ & - & Abdülkadir Efendi & - & - & - & 29 \\
\hline $1885^{90}$ & - & Abdülkadir Efendi & - & - & - & $41 / 29$ \\
\hline $1886^{91}$ & - & Abdülkadir Efendi & - & - & - & $41 / 30$ \\
\hline $1887^{92}$ & - & Abdülkadir Efendi & - & - & - & 35 \\
\hline $1888^{93}$ & - & Abdülkadir Efendi & - & - & - & $41 / 59$ \\
\hline $1889^{94}$ & - & Abdülkadir Efendi & - & - & - & 41 \\
\hline $1890^{95}$ & - & Abdülkadir Efendi & - & $\begin{array}{l}\text { İbrahim Rüşdi } \\
\text { Efendi }\end{array}$ & $\begin{array}{l}\text { Şeyh Bazur } \\
\text { Efendi }\end{array}$ & - \\
\hline $1891^{96}$ & - & Abdülkadir Efendi & - & $\begin{array}{l}\text { İsmail Yaver } \\
\text { Efendi }\end{array}$ & $\begin{array}{l}\text { Şeyh Bazur } \\
\text { Efendi }\end{array}$ & - \\
\hline $1892^{97}$ & - & Abdülkadir Efendi & - & Rüşdi Efendi & $\begin{array}{l}\text { Şeyh Bazur } \\
\text { Efendi }\end{array}$ & - \\
\hline $1894^{98}$ & - & Abdülkadir Efendi & - & $\begin{array}{c}\text { Mahmud } \\
\text { Nedim Efendi }\end{array}$ & Bazur Ağa & 50 \\
\hline $1895^{99}$ & - & Abdülkadir Efendi & - & - & - & - \\
\hline $1896^{100}$ & - & Abdülkadir Efendi & - & - & - & 70 \\
\hline $1897^{101}$ & - & Abdülkadir Efendi & - & - & - & - \\
\hline $1898^{102}$ & $\begin{array}{l}\text { Abdülkadir } \\
\text { Efendi (Vekil) }\end{array}$ & - & - & $\begin{array}{c}\text { Mahmud } \\
\text { Nedim Efendi }\end{array}$ & Bazur Ağa & $62 / 50$ \\
\hline $1899^{103}$ & $\begin{array}{l}\text { Abdülkadir } \\
\text { Efendi (Vekil) }\end{array}$ & - & - & $\begin{array}{c}\text { Mahmud } \\
\text { Nedim Efendi }\end{array}$ & Bazur Ağa & 50 \\
\hline $1900^{104}$ & $\begin{array}{l}\text { Mustafa Tevfik } \\
\text { Efendi(Vekil) }\end{array}$ & - & - & $\begin{array}{c}\text { Mahmud } \\
\text { Nedim Efendi }\end{array}$ & 1 & $46 / 48$ \\
\hline $1901^{105}$ & $\begin{array}{l}\text { Mustafa Tevfik } \\
\text { Efendi (Vekil) }\end{array}$ & - & - & $\begin{array}{c}\text { Mahmud } \\
\text { Nedim Efendi }\end{array}$ & 1 & 46 \\
\hline $1902^{106}$ & $\begin{array}{l}\text { Mustafa Tevfik } \\
\text { Efendi (Vekil) }\end{array}$ & - & - & $\begin{array}{c}\text { Mahmud } \\
\text { Nedim Efendi }\end{array}$ & - & 60 \\
\hline $1903^{107}$ & $\begin{array}{l}\text { Mustafa Tevfik } \\
\text { Efendi (Vekil) }\end{array}$ & $\begin{array}{c}\text { Muavin İsmail } \\
\text { Efendi }\end{array}$ & - & $\begin{array}{c}\text { Mahmud } \\
\text { Nedim Efendi }\end{array}$ & 1 & $40 / 60$ \\
\hline $1904^{108}$ & $\begin{array}{l}\text { Mustafa Tevfik } \\
\text { Efendi (Vekil) }\end{array}$ & $\begin{array}{l}\text { Riyaziye Muallimi } \\
\text { İsmail Efendi }\end{array}$ & - & $\begin{array}{c}\text { Mahmud } \\
\text { Nedim Efendi }\end{array}$ & $\begin{array}{c}\text { Molla Bazur } \\
\text { Ağa } \\
\end{array}$ & 60 \\
\hline $1905^{109}$ & $\begin{array}{l}\text { Mustafa Tevfik } \\
\text { Efendi (Vekil) }\end{array}$ & $\begin{array}{l}\text { Riyaziye Muallimi } \\
\text { İsmail Efendi }\end{array}$ & - & $\begin{array}{c}\text { Mahmud } \\
\text { Nedim Efendi }\end{array}$ & - & 62 \\
\hline $1906^{110}$ & $\begin{array}{l}\text { Hasan Tahsin } \\
\text { Efendi }\end{array}$ & - & - & $\begin{array}{c}\text { Mahmud } \\
\text { Nedim Efendi }\end{array}$ & $\begin{array}{c}\text { Şeyh Bazur } \\
\text { Ağa }\end{array}$ & 60 \\
\hline $1908^{111}$ & Abdullah Efendi & - & - & $\begin{array}{c}\text { Mahmud } \\
\text { Nedim Efendi }\end{array}$ & $\begin{array}{c}\text { Şeyh Bazur } \\
\text { A ğa }\end{array}$ & 50 \\
\hline
\end{tabular}

\section{Nizib Mülki Rüşdiye Mektebi}

Urfa Sancağı idari sınırları içinde yer alan Birecik kazasının Nizib köyünde bir rüşdiye mektebi açılması için ilk teşebbüs, tespit edilebildiği kadarıyla, 1894 yılı başlarında ahali tarafından yapılmıştır. Nizib halkının, köylerinde rüşdiye mektebi açılması için Birecik Kaymakamlığına gönderdiği 27 Ocak 1894 tarihli umumi dilekçede şu hususlara yer verilmiştir: 
“...Iddare-i seniyyeleri altında bulunan İslam, Hiristiyan ve Yahudi milletlerinden oluşan 1000 haneden fazla ve 10 kadar ibtidai mektebine sahip Nizib nahiyesinde dahi o şerefe mazhariyet ümidiyle birkaç seneden beri bir rüşdiye mektebinin yeri mevcut olduğu; gençlerimizin, maarif tahsili hususunda noksansı kabiliyetleri bulunduğu halde teessüf olunur ki resmi bir rüşdiye mektebinin açıllşıına nail olunamamıştır. Şu muvaffakıyetsizliğin devamıyla, vatanın ümidi olan çocukların cehalet içinde yuvarlanıp sosyal hayattan bir şey istifade edememesine Padişah 'in rızası olamayacaktır. Bu nedenle, lütuf ve merhamet eseri olarak memleketimizde resmi bir rüşdiye mektebinin açılması ile lazım olan muallimlerin tayin ve gönderilmesi vesilelerinin ikmali için durumun Maarif Nezaretine bildirilmesini arz ve istirham ederiz. "'48

Nizib ahalisinin dilekçesini görüşen Birecik İdare Meclisi, hem Nizib'in gelişmişlik durumunu ve hem de mektebin açllışıly ilgili olumlu kanaatini şu cümlelerle ifade etmiştir:

“...Ahalinin maarife olan şevk ve gayretleri ile çarşı ve pazarı mükemmel olduğu gibi; 700 haneye, camilere, mescidlere ve birkaç sıbyan mektebine sahib olduğundan ve mevkiinin de haiz olduğu ehemmiyet ve büyüklüğünden dolayı Nizib karyesinde bir rüşdiye mektebinin açılması ile icab eden muallimlerin tayini uygundur. Zaten rüşdiye mektebinin binaları ile odaları mevcut ve mükemmel olup, muallim maaşlarından başka hiçbir masrafı yoktur."

Birecik İdare Meclisinin bu mazbatasını ve ekindeki dilekçeyi değerlendiren Urfa Sancağı İdare Meclisine göre de hakikaten söz konusu kasaba her ne kadar karye (köy) sıfatıyla anılmakta ise de, mevkiinin ehemmiyet ve büyüklüğünden ve ahalisinin maarifle alakalı şevk ve gayretlerinden dolayı orada bir rüşdiye mektebinin açılması maarifin terakkisi nokta-i nazarından pek münasiptir. $\mathrm{Bu}$ nedenle, gerekli olan muallimler ile bevvabın tayin edilerek, sözü edilen mektebin teşkiline müsaade edilmesi gerekir (19 Temmuz 1894). ${ }^{49}$

Yapılan yazışmalar sonucunda mektebin açılması için gerekli olan iradenin çıktığı, 22 Ağustos 1895 tarihli Sadaret yazısında ifade edilmiştir. Gerekli müsaadeyi alan Maarif Nezareti, konuyu Maarif Muhasebe-i Umumiyye Dairesine havale ederek, mektebin eğitim-öğretim masraflarının belirlenmesini istemiştir. Burada yapılan değerlendirmede; Nizib Rüşdiye Mektebi muallim-i evvelliğine, hatt muallimliğiyle beraber, aylık 700, hademeliğine 80 ve yıllık çeşitli masraflarına da 500 kuruşun tahsisi uygun görülmüştür (3 Eylül 1895). ${ }^{50}$ Bunun üzerine, Meclis-i Kebir-i Maarifin 17 Ekim 1895 tarihli kararıyla, Darülmuallimin ve Mekteb-i Hukuk-1 Şahane mezunlarından Bekir Sıdkı Efendi, uhdesinde rika muallimliği de olmak üzere, aylık 700 kuruş maaşla söz konusu mektebe muallim-i evvel olarak atanmıştır. Akabinde Maarif Nezaretince kendisine yemin ettirilmiş ve harcırahı verilerek görev yerine gönderilmiştir. Bu durum, $22 \mathrm{Kas} ı \mathrm{~m}$ 1895 tarihli yazıyla da Haleb Vilayeti Maarif Müdürlüğüne bildirilmiştir. ${ }^{51}$

Mektebe muallim tayin edildikten sonra, Birecikli Hacı Ali Efendi de buraya bevvab olarak kabul edilmesi talebinde bulunmuştur. Bu talep, Meclis-i Kebir-i Maarif̧̧e onaylanarak, iyi halli olması ve iktidarının bulunması halinde, adı geçen şahsın yukarıda belirtilen maaşla mahallince

48 BOA, MF. MKT, 294/39, Nizib Karyesi ahalisinin Birecik Kaymakamlığına gönderdiği umumi dilekçe.

49 BOA, MF. MKT, 294/39, Urfa Sancağı İdare Meclisinden Haleb Vilayetine gönderilen 19 Temmuz 1894 (15 Muharrem 1312) tarihli mazbata.

50 BOA, MF. MKT, 294/39, Maarif Muhasebe-i Umumiyye Dairesinin 3 Eylül 1895 (22 Ağustos 1311) tarihli yazısı.

51 BOA, MF. MKT, 294/39, Maarif Nezaretinden Haleb Vilayeti Maarif Müdürlüğüne gönderilen 22 Kasım 1895 (4 Cemaziyülâhır 1313) tarihli yazı. 
bevvab olarak tayini hususunun Haleb Vilayeti Maarif Müdürlüğüne bildirilmesi uygun görülmüştür (17 Aralık 1895). ${ }^{52}$ Ancak, mektebin muallim-i evveli ile bevvabı atandığı halde, muallim-i evvel olarak tayin edilen Bekir Sıdkı Efendi görev yerine gitmemiştir. Bu nedenle de, açılması için büyük çaba sarf edilen Nizib Rüşdiye Mektebi eğitime başlayamamıştır. Bu durumda yeniden harekete geçen Haleb Vilayeti Maarif Müdürlüğü, yeni düzenlemeler gereği, söz konusu muallimlik maaşının aylık 500 kuruşa indirildiğini ifade ederek, bu miktar maaşla mektep için muktedir bir muallim-i evvelin tayinine müsaade edilmesini istemiştir (27 Mayıs 1897). ${ }^{53}$ Fakat yeni bir muallim-i evvelin atanabilmesi için Bekir Sıdkı Efendi'nin akıbetinin ne olduğunun bilinmesi ve kendisine ödenen yol harcırahının iade edilmesi gerekli görülmüştür. Bunun üzerine yapılan araştırmada, Bekir Sıdkı Efendi'nin başka bir memuriyete tayin olunduğu anlaşılmıştır. Bu nedenle, mektep için Darülmuallimin mezunlarından başka bir muallimin tayin edilerek, açılış töreninin icrasına müsaade edilmesi istenmiştir (1 Temmuz 1898)..$^{54}$ Böylece, ahali tarafından inşa edilen mektep, sözü edilen muallim yokluğu sıkıntısından dolayı ancak Sultan II. Abdülhamid Dönemi’nde R. 1315 (1899/1900) yılında açılabilmiştir. ${ }^{55}$

1899-1908 yılları arasında aktif olduğu tespit edilebilen mektebin eğitim ve yardımcı personel kadrosu ile talebe adedinin yıllara göre dağılımı aşağıdaki şekildedir:

Tablo 5. Nizib Mülki Rüşdiye Mektebi Personel ve Talebe Çizelgesi

\begin{tabular}{|c|l|l|c|l|c|c|}
\hline YIL & \multicolumn{1}{|c|}{$\begin{array}{c}\text { BíRÍNCI } \\
\text { MUALLIM }\end{array}$} & \multicolumn{1}{|c|}{$\begin{array}{c}\text { ÍKINCI } \\
\text { MUALLIM }\end{array}$} & $\begin{array}{c}\text { ÜÇÜNCÜ } \\
\text { MUALLIM }\end{array}$ & $\begin{array}{l}\text { HATT/RÍKA } \\
\text { MUALLIMII }\end{array}$ & $\begin{array}{c}\text { BEVVAB/ } \\
\text { HADEME/ } \\
\text { MUBASSIR }\end{array}$ & $\begin{array}{c}\text { TALEBE } \\
\text { ADEDİ }\end{array}$ \\
\hline $1899^{112}$ & $\begin{array}{l}\text { Abdullah Hilmi } \\
\text { Efendi }\end{array}$ & - & - & $\begin{array}{l}\text { Abdullah } \\
\text { Hilmi Efendi }\end{array}$ & 1 & 20 \\
\hline $1900^{113}$ & $\begin{array}{l}\text { Abdullah Hilmi } \\
\text { Efendi }\end{array}$ & - & - & $\begin{array}{l}\text { Abdullah } \\
\text { Hilmi Efendi }\end{array}$ & 1 & 43 \\
\hline $1901^{114}$ & $\begin{array}{l}\text { Abdullah Hilmi } \\
\text { Efendi }\end{array}$ & - & - & $\begin{array}{l}\text { Abdullah } \\
\text { Hilmi Efendi }\end{array}$ & 1 & 43 \\
\hline $1903^{115}$ & $\begin{array}{l}\text { Hasan Tahsin } \\
\text { Efendi (Vekil) }\end{array}$ & - & - & Hasan Efendi & 1 & 45 \\
\hline $1904^{116}$ & Hamid Efendi & $\begin{array}{l}\text { Riyaziye Muallimi } \\
\text { Hasan Tahsin } \\
\text { Efendi }\end{array}$ & - & - & Mustafa Ağa & 40 \\
\hline $1905^{117}$ & Münhal & $\begin{array}{l}\text { Muavini Mehmed } \\
\text { Nuri Efendi }\end{array}$ & - & - & - & 45 \\
\hline $1908^{119}$ & $\begin{array}{l}\text { Bekir Sidk1 } \\
\text { Efendi }\end{array}$ & $\begin{array}{l}\text { Muavini İsmail } \\
\text { Hakki Efendi }\end{array}$ & - & $\begin{array}{l}\text { Mustafa Lami' } \\
\text { Efendi }\end{array}$ & - & 46 \\
\hline
\end{tabular}

52 BOA, MF. MKT, 298/58, Mekatib-i Rüşdiye İdaresinin 17 Aralık 1895 (5 Kanun-i evvel 1311) tarihli yazisi.

53 BOA, MF. MKT, 294/39, Haleb Vilayeti Maarif Müdürlüğünden Maarif Nezaretine gönderilen 27 May1s 1897 (25 Zilhicce 1314) tarihli yazı.

54 BOA, MF. MKT, 294/39, Haleb Vilayeti Maarif Müdürlüğünden Maarif Nezaretine gönderilen 1 Temmuz 1898 (11 Safer 1316) tarihli yaz1.

55 Maarif Salnamesi, H. 1318, s. 1276-1277; H. 1319, s. 550-551. 


\section{Sonuç}

Osmanlı Devleti'nde, Tanzimat'ın ilanından sonra daha planlı bir şekilde yürütülen modernleşme çalışmaları, bilhassa eğitim alanında kısa sürede hem merkezde ve hem de taşrada etkisini göstermeye başlamıştır. Bu kapsamda, diğer vilayet ve sancaklarda olduğu gibi, bugünkü Şanlıurfa ili ve ilçelerinin önemli bir kısmını içine alan Urfa Sancağında da ilk açılan modern okullar erkek rüşdiye mektepleri olmuştur. Bunlar; Urfa Rüşdiye Mektebi, Birecik Rüşdiye Mektebi, Rumkale (Halfeti) Rüşdiye Mektebi ve Nizib Rüşdiye Mektebidir. Bölgedeki diğer sancak ve kazalarla karşılaştırıldığında, söz konusu okulların burada da hemen hemen aynı tarihlerde açıldığı anlaşılmaktadır. Bu okulların açılıp eğitime başlamasında karşılaşılan sorunların başında, yine birçok bölgede olduğu gibi, öğretmen ihtiyacının tam olarak karşılanamaması gelmiştir. Bölgeye atanan öğretmenler ise göreve başlamadan başka bir yere tayin istemişlerdir. Bu durum, okulların fiziki açıdan hazır olmasına rağmen, talebelerin eğitime başlamalarının gecikmesine neden olmuştur.

Urfa Sancağında açılan rüşdiye mekteplerinde ilk yıllarda zaman zaman öğretmen eksikliği sıkıntısı yaşanmıştır. Fakat zamanla Hacı Abdurrahim Efendi, Mehmed Said Efendi, İhsan Bey, Abdurrahman Efendi, Mehmed Şerif Efendi, Salih Hayali Efendi, Mustafa Nef'i Efendi, Abdülkadir Efendi ve Abdullah Hilmi Efendi gibi zatlar uzun yıllar bu okullarda öğretmenlik yapmışlardır. Burada bilhassa öğretmen yokluğundan kaynaklanabilecek eğitim-öğretim aksamalarına meydan vermemek için okullar genellikle sene içerisinde boş bırakılmamıştır. Tatillerde ve hastalık gibi çok zaruri durumlarda bile öğretmenlerin uzun süreli izin kullanmalarına müsaade edilmemiş veya mutlaka yerlerine vekâleten başka bir muallim tayin edilmiştir.

Urfa ve çevresinde açılan söz konusu rüşdiye mektepleri, ilk açılan modern okullar olması hasebiyle, bölgede çok sayıda yeni ibtidai mektebi ile idadi ve sanayi mekteplerinin açılmasına da öncülük etmiştir. Ayrıca, Urfa bölgesindeki sıbyan ve ibtidai mezunlarının eğitimlerini kendi memleketlerinde sürdürmelerine imkân sağlayarak, yıllara göre her bir okulda sayıları 20 ile 90 arasında değişen çok sayıda talebenin modern eğitim tarzına uygun olarak yetişmesine zemin hazırlamıştır. İlk zamanlarda rüşdiye mekteplerine çok fazla rağbet gösterilmemekle birlikte, daha sonraki yıllarda talebe sayısında hızlı bir artış olmuştur.

Osmanlı ülkesinin pek çok yerinde olduğu gibi, Urfa bölgesinde açılan rüşdiyelerin de inşa masraflarının hemen hemen tamamı, fedakâr ve eğitim sever olan yöre halkı tarafından karşılanmıştır. Merkezden ise sadece öğretmen maaşları ile eğitim-öğretimde kullanılacak kitap, risale ve harita gibi araç-gereçler istenmiştir. Bu öğretim materyali, imkânlar ölçüsünde Maarif Nezaretince tedarik edilerek bölgeye gönderilmiştir.

Dönemin bütün mali sıkıntılarına ve yetişmiş eleman azlığına rağmen, Maarif Nezaretinin teşviki ve yöre halkı ile mahalli idarecilerin gayretleri neticesinde, bölgede modern ortaokul eğitimi yapan rüşdiye mekteplerinin uzun yıllar aktif olması sağlanmıştır. Böylece genç nesillerin yetişmesine ciddi destek verilmiştir. 
Kaynakça

Arşiv Belgeleri

Başbakanlık Osmanlı Arşivi, Babıâli Evrak Odası (BOA, BEO)

Başbakanlık Osmanlı Arşivi, Şura-yı Devlet Evrakı (BOA, ŞD)

Başbakanlık Osmanlı Arşivi, İrade Dâhiliye Evrakı (BOA, İ. DH)

Başbakanlık Osmanlı Arşivi, Dâhiliye Mektubi Evrakı ( BOA, DH. MKT)

Başbakanlık Osmanlı Arşivi, Maarif Mektubi Evrakı (BOA, MF. MKT)

Salnameler

Maarif Salnameleri

Haleb Vilayet Salnameleri

Osmanlı Devlet Salnameleri

\section{Telif Eserler} 1999.

Akyüz, Yahya, Türk Eğitim Tarihi (Başlangıçtan 1999’a), Alfa Yayınları, İstanbul

Ata, Bahri, “Osmanlı İmparatorluğu Döneminde Bir Ders Araç ve Gereçleri Lojistik Merkezi: Maarif Kütüphanesi (1872-1895).' 'Tarihin Peşinde: Uluslararası Tarih ve Sosyal Araştırmalar Dergisi, 1, (2009), s. 27-36.

Ekinci, Abdullah - Paydaş, Kazım, "Kuruluşundan Osmanlı Hâkimiyetine: Urfa Siyasi Tarihi”, Osmanlı Urfası, Cilt: 1, Editör: Abdullah Ekinci, İstanbul 2018.

Demirel, Muammer, "Türk Eğitiminin Modernleşmesinde Rüşdîye Mektepleri." Türkler, C. 15, Yeni Türkiye Yayınları, Ankara 2002, s. 64-93.

Kodaman, Bayram, Abdülhamid Devri Eğitim Sistemi, Türk Tarih Kurumu Yayınları, Ankara 1991.

Öztürk, Şehnaz, Tanzimat'tan Cumhuriyet'e Urfa'da Eğitim, Yayımlanmamış Yüksek Lisans Tezi, Harran Üniversitesi Sosyal Bilimler Enstitüsü, Şanlıurfa 2006.

Ünal, Uğur, Meclis-i Kebir-i Maarif (1869-1922), Türk Tarih Kurumu Yayınları, Ankara 2008.

Üner, Mehmet Emin, Osmanlı Klasik Dönem Sonlarında Bir Güneydoğu Anadolu Şehri: Urfa (1700-1800), Yayınlanmamış Doktora Tezi, İstanbul Üniversitesi Sosyal Bilimler Enstitüsü, İstanbul 2003.

Yıldız, Hatip, “Osmanlı Devleti’nde Mülki (Sivil) Erkek Rüşdiye Muallimlerinin 
Nitelikleri, Hakları ve Sorumlulukları", History Studies, A Tribute to Prof. Dr. Şerafettin Turan, Volume 6, Issue 3, April 2014, p. 369-382.

\section{Ekler}

Ek.1. Birecik ve Rumkale Rüşdiye Mektebleri için Haleb Vilayeti’ne gönderilen kitap ve risalelerin listesi

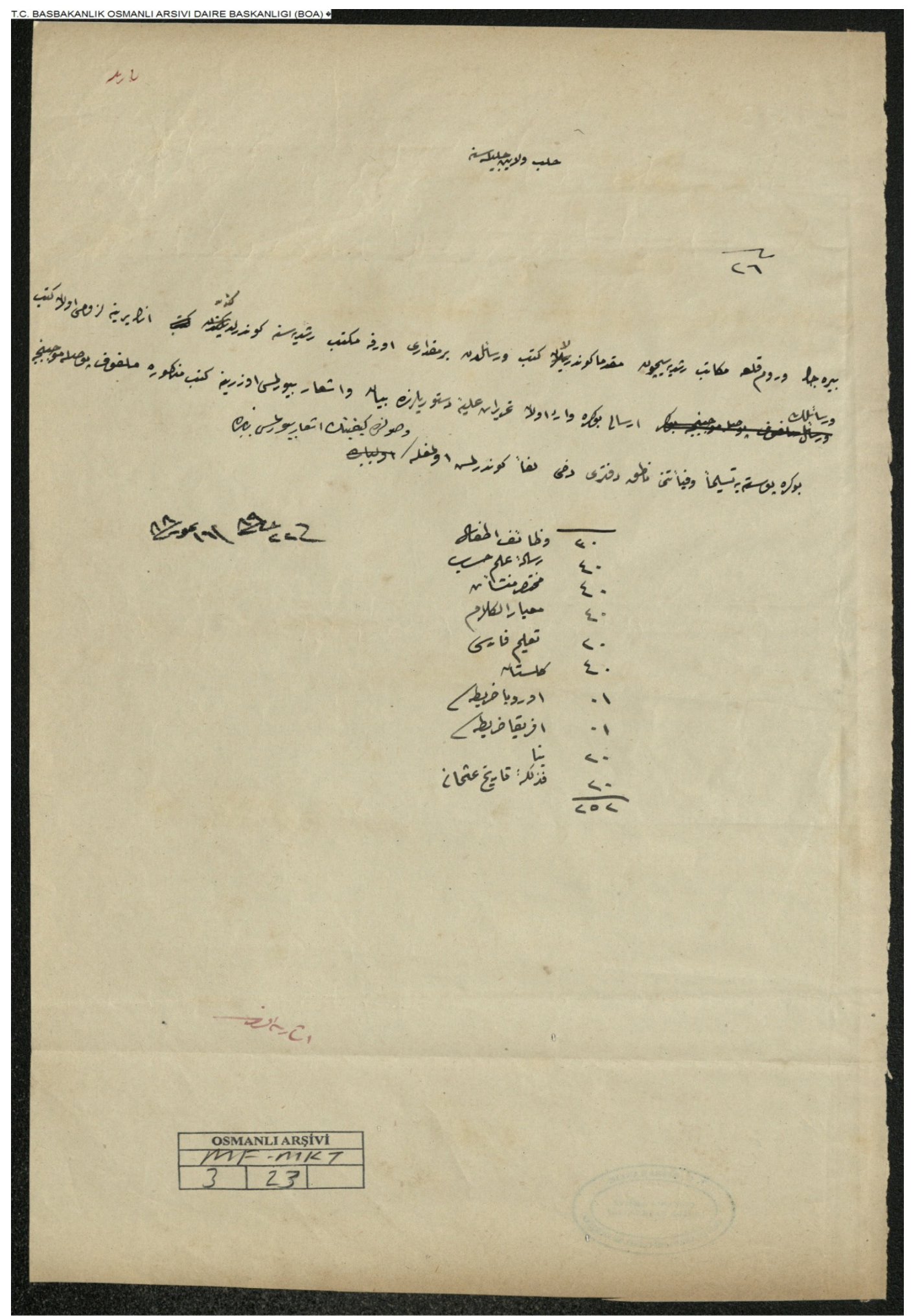


Ek. 2. Urfa Sancağı Belediye Tabibinin Urfa Rüşdiye Mektebi Muallim-i Evveli Hacı Abdurrahim Efendi'ye Verdiği 31 Teşrin-i evvel 1303 Tarihli Sağlık Raporu

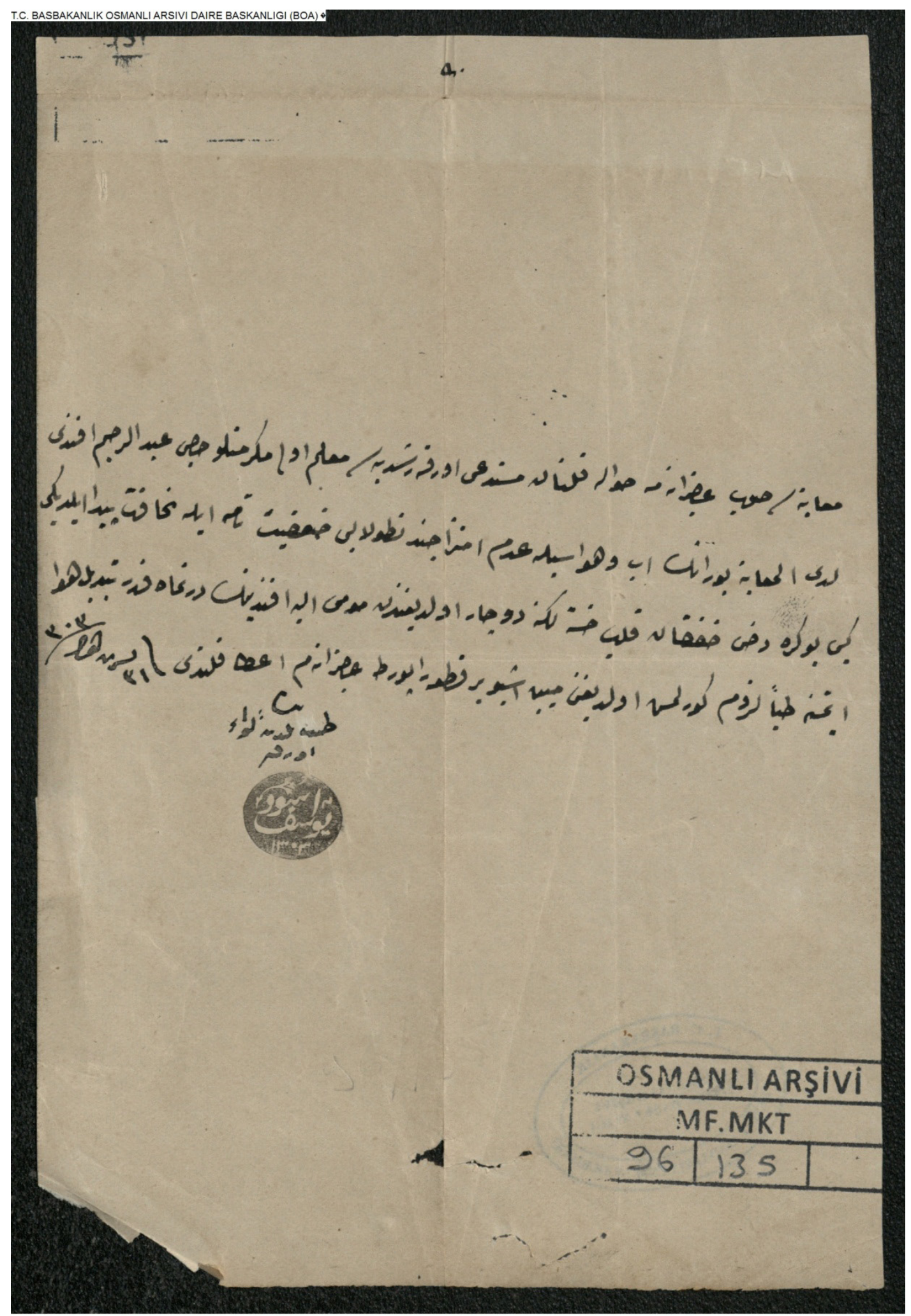


Ek. 3. Nizib Karyesi Ahalisinin Birecik Kaymakamlığı’na Yazdığı Umumi Dilekçe

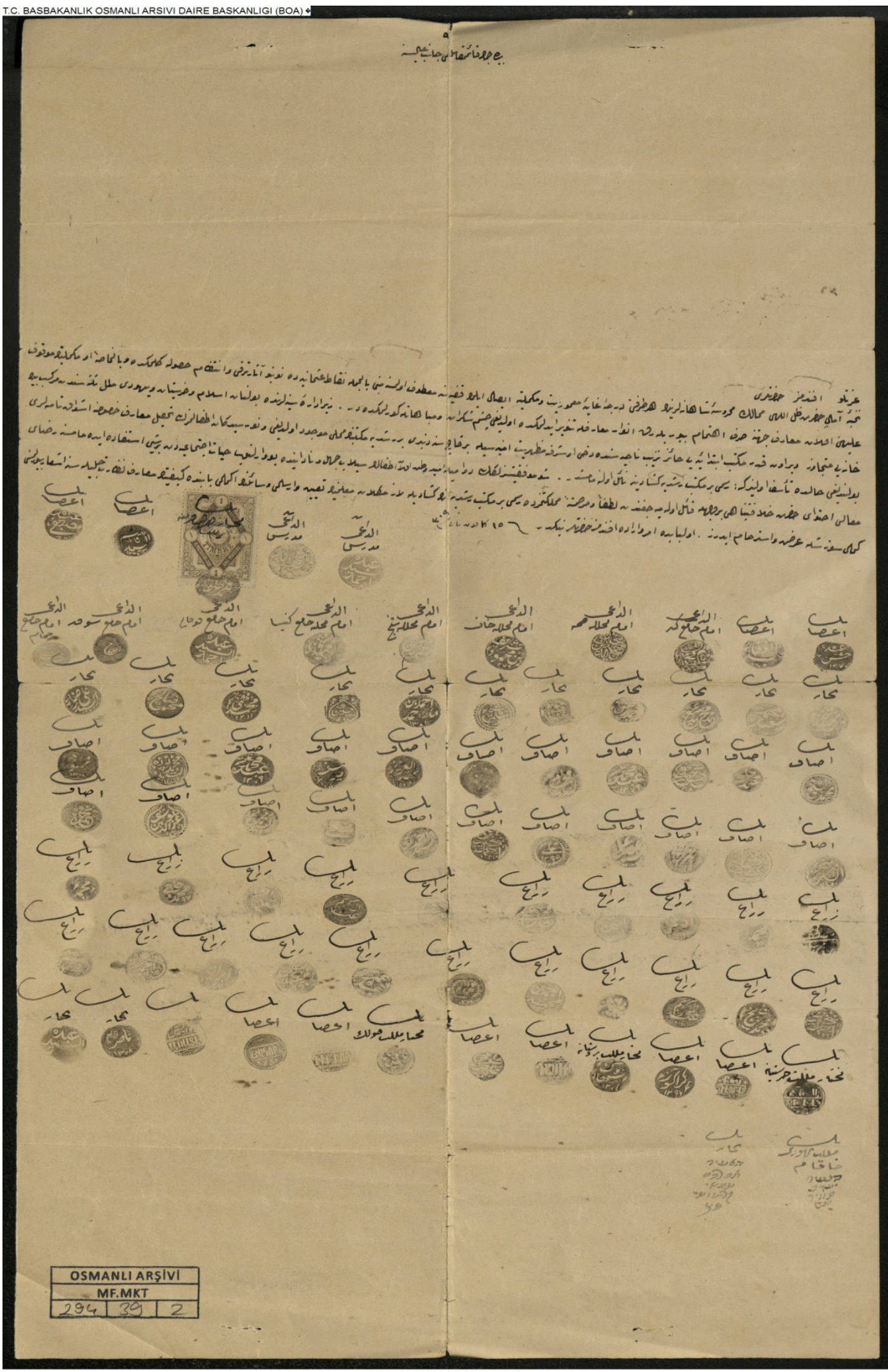




\section{Tablolarda kullanılan dipnotlar}

$1 \mathrm{Bu}$ tarihte mektebin kaydı olmakla birlikte, muallim ve talebe adedine yer verilmemiştir. Bkz. Haleb Vilayet Salnamesi, H. 1287, s. 76.

2 Osmanlı Devlet Salnamesi, H. 1288, s. 146; Haleb Vilayet Salnamesi, H. 1288, s. 75.

3 Osmanlı Devlet Salnamesi, H. 1289, s. 240; Haleb Vilayeti Salnamesi, H. 1289, s. 73.

4 Osmanlı Devlet Salnamesi, H. 1290, s. 213.

5 Osmanlı Devlet Salnamesi, H. 1291, s. 219.

6 Osmanl1 Devlet Salnamesi, H. 1292, s. 158.

7 Osmanlı Devlet Salnamesi, H. 1293, s. 161;

8 Osmanlı Devlet Salnamesi, H. 1294, s. 538.

$9 \mathrm{Bu}$ tarihte mektebin adına yer verildiği halde, diğer özelliklerinden söz edilmemektedir. Bkz. Osmanlı Devlet Salnamesi, H. 1295, s. 433.

$10 \mathrm{Bu}$ tarihte mektebin adına yer verilmiş olup, diğer özelliklerinden söz edilmemektedir. Bkz. Osmanlı Devlet Salnamesi, H. 1296, s. 184.

$11 \mathrm{Bu}$ tarihte mektebin adına yer verilmiş olup, diğer özelliklerinden söz edilmemektedir. Bkz. Osmanlı Devlet Salnamesi, H. 1297, s. 254.

12 Osmanlı Devlet Salnamesi, H. 1298, s. 283.

13 Osmanl1 Devlet Salnamesi, H. 1299, s. 275.

14 Haleb Vilayet Salnamesi, H. 1300, s. 116; Osmanlı Devlet Salnamesi, H. 1300, s. 211.

15 Osmanli Devlet Salnamesi, H. 1301, s. 396.

16 Haleb Vilayet Salnamesi, H. 1302, s. 204; Osmanlı Devlet Salnamesi, H. 1302, s. 418; MF. MKT, $85 / 79$. 
17 Haleb Vilayet Salnamesi, H. 1303, s. 225; Osmanlı Devlet Salnamesi, H. 1303, s. 338.

18 Osmanl1 Devlet Salnamesi, H. 1304, s. 324; BOA, MF. MKT, 96/135.

19 Haleb Vilayet Salnamesi, H. 1305, s. 215; Osmanlı Devlet Salnamesi, H. 1305, s. 251; MF. MKT, $275 / 73$.

20 Haleb Vilayet Salnamesi, H. 1306, s. 213.

21 Haleb Vilayet Salnamesi, H. 1307, s. 106.

22 Haleb Vilayet Salnamesi, H. 1308, s. 229.

23 Haleb Vilayet Salnamesi, H. 1309, s. 160.

24 Haleb Vilayet Salnamesi, H. 1310, s. 249; BOA, MF. MKT, 168/68.

25 Haleb Vilayet Salnamesi, H. 1312, s. 293.

26 Haleb Vilayet Salnamesi, H. 1313, s. 278.

27 Haleb Vilayet Salnamesi, H. 1314, s. 262.

28 Haleb Vilayet Salnamesi, H. 1315, s. 267.

29 Maarif Salnamesi, H. 1316, s. 1012; Haleb Vilayet Salnamesi, H. 1316, s. 293.

30 Maarif Salnamesi, H. 1317, s. 1112; Haleb Vilayet Salnamesi, H. 1317, s. 293.

31 Maarif Salnamesi, H. 1318, s. 1254; Haleb Vilayet Salnamesi, H. 1318, s. 308.

32 Maarif Salnamesi, H. 1319, s. 532.

33 Haleb Vilayet Salnamesi, H. 1320, s. 326.

34 BOA, ŞD, 2212/49.

$35 \mathrm{Bu}$ tarihte mektebin kaydı olmakla birlikte, henüz muallim tayin edilmediği belirtilmiştir. Bkz. Haleb Vilayeti Salnamesi, H. 1287, s. 76; Osmanlı Devlet Salnamesi, H. 1287, s. 127.

$36 \mathrm{Bu}$ tarihte mektebin kaydı olmakla birlikte, muallim ve talebe adedine yer verilmemiştir. Bkz. Haleb Vilayeti Salnamesi, H. 1288, s. 75; Osmanlı Devlet Salnamesi, H. 1288, s. 146. 
37 Osmanl1 Devlet Salnamesi, H. 1289, s. 240; Haleb Vilayeti Salnamesi, H. 1289, s. 73.

38 Osmanlı Devlet Salnamesi, H. 1290, s. 213.

39 Osmanl1 Devlet Salnamesi, H. 1291, s. 219.

40 Osmanlı Devlet Salnamesi, H. 1292, s. 158.

41 Osmanli Devlet Salnamesi, H. 1293, s. 161.

42 Osmanlı Devlet Salnamesi, H. 1294, s. 538.

$43 \mathrm{Bu}$ tarihte mektebin adına yer verilmiş olup, diğer özelliklerinden söz edilmemektedir. Bkz. Osmanlı Devlet Salnamesi, H. 1295, s. 433.

$44 \mathrm{Bu}$ tarihte mektebin adına yer verilmiş olup, diğer özelliklerinden söz edilmemektedir. Bkz. Osmanlı Devlet Salnamesi, H. 1296, s. 184.

$45 \mathrm{Bu}$ tarihte mektebin adına yer verilmiş olup, diğer özelliklerinden söz edilmemektedir. Bkz. Osmanlı Devlet Salnamesi, H. 1297, s. 255.

46 Osmanlı Devlet Salnamesi, H. 1298, s. 283.

47 Osmanli Devlet Salnamesi, H. 1299, s. 275.

48 Haleb Vilayet Salnamesi, H. 1300, s. 116; Osmanl1 Devlet Salnamesi, H. 1300, s. 211.

49 Osmanli Devlet Salnamesi, H. 1301, s. 396.

50 Haleb Vilayet Salnamesi, H. 1302, s. 204; Osmanlı Devlet Salnamesi, H. 1302, s. 418.

51 Haleb Vilayet Salnamesi, H. 1303, s. 225; Osmanlı Devlet Salnamesi, H. 1303, s. 338.

52 Osmanli Devlet Salnamesi, H. 1304, s. 324.

53 Haleb Vilayet Salnamesi, H. 1305, s. 215; Osmanl1 Devlet Salnamesi, H. 1305, s. 250.

54 Haleb Vilayet Salnamesi, H. 1306, s. 213.

55 Haleb Vilayet Salnamesi, H. 1307, s. 106.

56 Haleb Vilayet Salnamesi, H. 1308, s. 231. 
57 Haleb Vilayet Salnamesi, H. 1309, s. 161.

58 Mahmud Lami' Efendi, Birecik Rüşdiye Mektebi muallim-i evveli iken, 20 yıllık güzel hizmetine binaen, 1 Eylül 1892 (8 Safer 1310) tarihli hususi irade doğrultusunda aylık 2000 kuruş maaşla İstanbul'da Adliye Dairesinde istihdamı kararlaştırılmıştır. Ancak, üç ay sonra çıkan başka bir iradeyle aynı maaşla Maarif Meclisi azalığına tayini uygun görülmüş ve durum Maarif Nezaretine bildirilmiştir. Bkz. BOA, İ. HUS, 3/43; BOA, BEO, 61/4574; BOA, BEO, 112/8370.

59 Haleb Vilayet Salnamesi, H. 1312, s. 303.

60 Haleb Vilayet Salnamesi, H. 1313, s. 286.

61 Haleb Vilayet Salnamesi, H. 1314, s. 271.

62 Haleb Vilayet Salnamesi, H. 1315, s. 276.

63 Maarif Salnamesi, H. 1316, s. 1012; Haleb Vilayet Salnamesi, H. 1316, s. 303.

64 Maarif Salnamesi, H. 1317, s. 1112; Haleb Vilayet Salnamesi, H. 1317, s. 303.

65 Maarif Salnamesi, H. 1318, s. 1254-1255; Haleb Vilayet Salnamesi, H. 1318, s. 319.

66 Maarif Salnamesi, H. 1319, s. 532.

67 Haleb Vilayet Salnamesi, H. 1320, s. 336.

68 Maarif Salnamesi, H. 1321, s. 460; Haleb Vilayet Salnamesi, H. 1321, s. 395.

69 Haleb Vilayet Salnamesi, H. 1322, s. 409.

70 Haleb Vilayet Salnamesi, H. 1323, s. 426.

71 Haleb Vilayet Salnamesi, H. 1324, s. 419.

72 Muallim-i sani Salih Hayali Efendi'nin memuriyetinin 1907 yılı başlarında tasdik edildiği; 1908 yılı başlarında ise kendisine 6 aylık izin verildiği anlaşılmaktadır. Bkz. MF. MKT, 980/57; MF. MKT, $1037 / 13$.

73 Haleb Vilayet Salnamesi, H. 1326, s. 418.

74 BOA, MF. MKT, 1155/107.

75 Osmanlı Devlet Salnamesi, H. 1287, s.127. 
76 Osmanl1 Devlet Salnamesi, H. 1288, s. 146.

77 Osmanli Devlet Salnamesi, H. 1289, s. 240.

78 Osmanlı Devlet Salnamesi, H. 1290, s. 213.

79 Osmanl1 Devlet Salnamesi, H. 1291, s. 219.

80 Osmanl1 Devlet Salnamesi, H. 1292, s. 158.

81 Osmanl1 Devlet Salnamesi, H. 1293, s. 161.

82 Osmanlı Devlet Salnamesi, H. 1294, s. 536.

83 Bu tarihte mektebin adına yer verilmiş olup, diğer özelliklerinden söz edilmemektedir. Bkz. Osmanlı Devlet Salnamesi, H. 1295, s. 433.

84 Bu tarihte mektebin adına yer verilmiş olup, diğer özelliklerinden söz edilmemektedir. Bkz. Osmanlı Devlet Salnamesi, H. 1296, s. 184.

85 Bu tarihte mektebin adına yer verilmiş olup, diğer özelliklerinden söz edilmemektedir. Bkz. Osmanlı Devlet Salnamesi, H. 1297, s. 254.

86 Osmanlı Devlet Salnamesi, H. 1298, s. 283.

87 Osmanlı Devlet Salnamesi, H. 1299, s. 275.

88 Haleb Vilayet Salnamesi, H. 1300, s. 116; Osmanlı Devlet Salnamesi, H. 1300, s. 211.

89 Osmanl1 Devlet Salnamesi, H. 1301, s. 396.

90 Haleb Vilayet Salnamesi, H. 1302, s. 204; Osmanlı Devlet Salnamesi, H. 1302, s. 418.

91 Haleb Vilayet Salnamesi, H. 1303, s. 225; Osmanlı Devlet Salnamesi, H. 1303, s. 338.

92 Osmanlı Devlet Salnamesi, H. 1304, s. 324.

93 Haleb Vilayet Salnamesi, H. 1305, s. 215; Osmanlı Devlet Salnamesi, H. 1305, s. 250.

94 Haleb Vilayet Salnamesi, H. 1306, s. 213.

95 Haleb Vilayet Salnamesi, H. 1307, s. 106. 
96 Haleb Vilayet Salnamesi, H. 1308, s. 233.

97 Haleb Vilayet Salnamesi, H. 1309, s. 162.

98 Haleb Vilayet Salnamesi, H. 1312, s. 307.

$99 \mathrm{Bu}$ tarihte kazada bir rüşdiye mektebinin varlığından söz edilmekte, fakat muallim ve talebe durumuna değinilmemektedir. Bkz. Haleb Vilayet Salnamesi, H. 1313, s. 290.

100 BOA, MF. MKT, 335/34, Rumkale Kazası İdare Meclisinin 25 Temmuz 1896 (14 Safer 1314) tarihli mazbatas1; BOA, MF. MKT, 334/45.

101 BOA, MF. MKT, 480/7.

102 Maarif Salnamesi, H. 1316, s. 1012; Haleb Vilayet Salnamesi, H. 1316, s. 307.

103 Maarif Salnamesi, H. 1317, s. 1112; Haleb Vilayet Salnamesi, H. 1317, s. 307.

104 Maarif Salnamesi, H. 1318, s. 1255; Haleb Vilayet Salnamesi, H. 1318, s. 323.

105 Maarif Salnamesi, H. 1319, s. 533.

106 Bu tarihte ilk defa Riyaziye Muallimi İsmail Hakkı Efendi'nin adına da yer verilmiştir (Bkz. Haleb Vilayet Salnamesi, H. 1320, s. 342). Sonraki yılda da aynı kişiden söz edilmiştir. Bkz. Haleb Vilayet Salnamesi, H. 1321, s. 402.

107 Maarif Salnamesi, H. 1321, s. 460; Haleb Vilayet Salnamesi, H. 1321, s. 402.

108 Haleb Vilayet Salnamesi, H. 1322, s. 418.

109 Haleb Vilayet Salnamesi, H. 1323, s. 435.

110 Haleb Vilayet Salnamesi, H. 1324, s. 429.

111 Haleb Vilayet Salnamesi, H. 1326, s. 427.

112 Maarif Salnamesi, H. 1317, s. 1112.

113 Maarif Salnamesi, H. 1318, s. 1255.

114 Maarif Salnamesi, H. 1319, s. 533. 
115 Maarif Salnamesi, H. 1321, s. 460; Haleb Vilayet Salnamesi, H. 1321, s. 395.

116 Haleb Vilayet Salnamesi, H. 1322, s. 409.

117 Haleb Vilayet Salnamesi, H. 1323, s. 426.

118 Haleb Vilayet Salnamesi, H. 1324, s. 419.

119 Haleb Vilayet Salnamesi, H. 1326, s. 418.

120 BOA, MF. MKT, 1051/24. 